Article

\title{
An Integrated Multi-Approach to Environmental Monitoring of a Self-Burning Coal Waste Pile: The São Pedro da Cova Mine (Porto, Portugal) Study Case
}

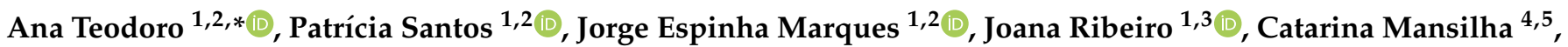 \\ Armindo Melo ${ }^{4,5}$, Lia Duarte ${ }^{1,2}\left(\mathbb{D}\right.$, Cátia Rodrigues de Almeida ${ }^{2} \mathbb{(}$ and Deolinda Flores ${ }^{1,2} \mathbb{C}$ \\ 1 Institute of Earth Sciences, University of Porto Pole, Porto Pole, 4169-007 Porto, Portugal; \\ patricia.santos@fc.up.pt (P.S.); jespinha@fc.up.pt (J.E.M.); joana.ribeiro@uc.pt (J.R.); liaduarte@fc.up.pt (L.D.); \\ dflores@fc.up.pt (D.F.) \\ 2 Department of Geosciences, Environment and Spatial Planning, Faculty of Sciences, University of Porto, \\ 4169-007 Porto, Portugal; up201600831@edu.fc.up.pt \\ 3 Departament of Earth Sciences, University of Coimbra, 3004-531 Coimbra, Portugal \\ 4 Instituto Nacional de Saúde Doutor Ricardo Jorge, 1649-016 Lisbon, Portugal; \\ catarinamansilha@gmail.com (C.M.); ajamelo@ff.up.pt (A.M.) \\ 5 REQUIMTE, Universidade do Porto, 4051-401 Porto, Portugal \\ * Correspondence: amteodor@fc.up.pt
}

check for updates

Citation: Teodoro, A.; Santos, P.; Espinha Marques, J.; Ribeiro, J.; Mansilha, C.; Melo, A.; Duarte, L.; Rodrigues de Almeida, C.; Flores, D. An Integrated Multi-Approach to Environmental Monitoring of a Self-Burning Coal Waste Pile: The São Pedro da Cova Mine (Porto, Portugal) Study Case. Environments 2021, 8, 48. https://doi.org/10.3390/ environments 8060048

Academic Editors: Delia Evelina Bruno and Eloisa Di Sipio

Received: 16 April 2021

Accepted: 17 May 2021

Published: 25 May 2021

Publisher's Note: MDPI stays neutral with regard to jurisdictional claims in published maps and institutional affiliations.

Copyright: (c) 2021 by the authors. Licensee MDPI, Basel, Switzerland. This article is an open access article distributed under the terms and conditions of the Creative Commons Attribution (CC BY) license (https:/ / creativecommons.org/licenses/by/ $4.0 /)$.

\begin{abstract}
The São Pedro da Cova waste pile (Porto, Portugal) is composed of coal mining residues that have been self-burning since 2005 and is located close to an inhabited area and social infrastructures, further adding to effects on the environment and human health. Therefore, there is a great interest in the environmental monitoring of this waste pile. This work describes an integrative multi-approach that allows the environmental monitoring of several parameters of the waste pile, applying several technologies. The temperature measurements were obtained by a thermal infrared (TIR) sensor on board an unmanned aerial vehicle (UAV) and supplemented with field measurements. In order to evaluate the altimetric variations, for each flight, a digital elevation model (DEM) was generated considering a multispectral sensor also on board the UAV. The hydrogeochemical characterization was performed through the analysis of groundwater and surface water samples, with and without the influence of mine drainage. The soil monitoring included the analysis of waste material as well as the surface soil in the surrounding area of the waste pile. All the data were analyzed and integrated in a geographical information system (GIS) open-source application. The adopted multi-approach methodology, given its intrinsic interdisciplinary character, has proven to be an effective way of encompassing the complexity of this type of environmental problem.
\end{abstract}

Keywords: temperature; soils; water quality; geographical information system; unmanned aerial vehicles; land use land cover

\section{Introduction}

Environmental monitoring is an integral part of management systems and a key tool to support decision-makers and to provide widely available information to the general public. Environmental monitoring can be achieved using in situ data collection, complemented by measurements at global and regional scales, whereby remote sensing data have proven to be very suitable [1].

Regarding mining areas, the environmental problems were mainly caused by mining itself and influenced by different factors, such as the regional economy, the population and urbanization [2]. Several methods and approaches have been proposed regarding the reclamation of mine sites, in order to attenuate the damaging effects of mining and recover the landscape and its immediate surroundings. These studies include the land use, vegetation and landscape pattern changes and their ecological effects [3], and ecological 
vulnerability, stability and risk [4-6]. Mining is also considered to be one of the most significant sources of heavy metal contamination and, consequently, a severe problem in many parts of the world [7]. Several studies on soil pollution related to mining activities and the potential ecological and human risks have been carried out in recent years, e.g., $[8,9]$.

There are several definitions in the literature for multi-approach or mixed methods [10]. In general, a multi-approach combines elements of qualitative and quantitative research approaches (e.g., use of qualitative and quantitative viewpoints, data collection, analysis, inference techniques) for the broad purposes of gaining a breadth and depth of understanding and corroboration [10]. Zakhem and Hafez (2015) [11] applied a multi-approach methodology using hydrochemistry, environmental stable isotopes and multivariate statistical analysis to identify the sources and distributions of groundwater nitrate pollution in the Damascus Oasis. Smith et al. (2020) [12] used a multi-approach to assess the impact of land use with physicochemical data, multivariate analyses, hydrogeochemistry and nitrate isotopic composition, in order to identify the major contributors of changes in groundwater quality, comparing two contrasting land uses in a karstic area of the Yucatan Peninsula (Mexico) as a case study. Duarte et al. (2016) [13] proposed an environmental integrated management system to minimize the impacts of the development of a radio astronomical infrastructure on the ecosystem and landscape, based on a geographic information system (GIS), which combines several functionalities and the creation of multiple maps regarding the digital elevation model (DEM), land use land cover (LULC), normalized difference vegetation index (NDVI), groundwater vulnerability, erosion risk, flood risk and forest fire risk. The proposed environmental integrated management system allowed monitoring and assessing different environmental factors and finding the optimal sites for the radio astronomical infrastructure.

GIS is usually combined with a multi-criteria evaluation approach in environmental analysis, providing tools that allow overlaying and combining different types of geospatial information to help with better decision making [14]. GIS can also provide univariate and multivariate statistics algorithms to apply in different contexts $[15,16]$. In the context of geo-environmental assessment in a coalfield, Sarkar et al. (2007) [17] proved that the applicability and usefulness of GIS combined with a multi-criteria evaluation approach were determinant for the delineation of environmentally affected zones in a coalfield in Jharia, consequently ensuring ecological sustainable development. Lin et al. (2020) [18] also used a GIS-based multi-criteria decision analysis approach to address public health regarding abandoned uranium mines and therefore to evaluate the risk and vulnerability considering different environmental factors. Flores et al. (2021) [19] mapped hydrogeochemical properties to assess the extent of acid mine drainage in waters (Tintillo River, Spain). The authors integrated drone-based visible to near-infrared (VNIR) hyperspectral data with physicochemical parameters of water (field and laboratory) to map acidity, redox potential and metal concentrations in surface water, considering a machine learning approach (the random forest algorithm) to map gradual changes occurring in the water properties.

Several works have also indicated the possibility of applying field and remote sensing data to identify minerals containing heavy metals as an indicator of contamination in mining areas [20,21]. There is an evident emergent use of UAV coupled with hyperspectral sensors to collect data at a higher spatial resolution than most aircraft and satellite counterparts, resulting in greater precision $[19,22]$, and to propose an object-oriented open-pit mine mapping framework from high-spatial resolution (HSR) satellite images, based on convolutional neural networks (CNNs). With this approach, researchers have provided a reliable technical approach to support the management and environmental monitoring of open-pit mining areas, and which can be applicable to other kinds of land use mapping in mining areas using HSR images. Kope' et al. (2020) [23] carried out a study regarding the environmental impact of underground coal mining in the Bogdanka mine, Poland, where spectral indexes, satellite radar interferometry, GIS tools and machine learning algorithms were utilized. Based on optical, radar, geological, hydrological and meteorological data, a 
spatial model was developed to determine the statistical significance of the selected factors' individual impact on the occurrence of wetlands.

The project ECOAL (Ecological Management of Coal Waste Piles in Combustion) was developed aiming at remote, multi-point and continuous monitoring of gas emissions and combustion temperature in a self-burning coal waste pile using optical fiber sensing technology. An application to produce dynamic temperature maps and videos representing the spatial and temporal variations in temperature under a GIS open-source environment (QGIS software) was developed, which allowed the monitoring of temperature variations and their relation to weather conditions, the evaluation of the temperature dynamics, continuous visualization of selected areas and the identification of possible/probable evolution scenarios and of new combustion areas [24].

The study of the São Pedro da Cova waste pile is of great importance as it has been self-burning since 2005, after ignition by forest fires, with the emission of gaseous and particulate matter to the atmosphere prompting environmental and human health impacts. Previous studies on the São Pedro da Cova waste pile approached the comprehensive characterization of the waste material, the identification of the combustion by-products (namely, gaseous volatile organic compounds and coal fire gas minerals) and the identification of potential environmental impacts in the surrounding environment, including soils, waters, ecosystems and human health [24-32]. There is a great interest in the environmental monitoring of the São Pedro da Cova waste pile. The main innovation and the overall objective of this work is related to the integration of data acquired through several methodologies (multi-approach), allowing the environmental monitoring of the São Pedro da Cova waste pile. The specific objectives of this work are: (i) to estimate the environmental impacts of the waste pile in the surrounding environment, namely, combustion temperature, landfill evolution and effects on nearby soils and waters based on in situ analysis and remote sensing data; and (ii) to develop a GIS open-source application (Coal Mine) to integrate all data with the purpose of quantitatively describing the spatial distribution of the contaminated area and to characterize the environmental and health risks.

\section{Materials and Methods}

In this work, the São Pedro da Cova waste pile and the surrounding areas will be studied considering the integration of several methodologies, as described in the workflow presented in Figure 1. This multi-approach, which allows the environmental monitoring of several parameters of the waste pile and the surrounding areas, integrates the following: (i) temperature monitoring (waste pile); (ii) altimetric analysis (waste pile); (iii) LULC (waste pile); (iv) hydrogeochemical characterization (waste pile surrounding areas); and (v) soil characterization (waste pile and surrounding areas). The extension of the soil monitoring outside the mine waste pile is intended to gain a better understanding of the contamination extent and magnitude on the surrounding soils. The hydrogeological inventory did not identify any relevant water points close to the mine facilities and the coal waste pile. For this reason, the hydrogeochemical characterization was carried out based on the mine drainage galleries, which emerge around $1000 \mathrm{~m}$ to the southeast of the waste pile. 


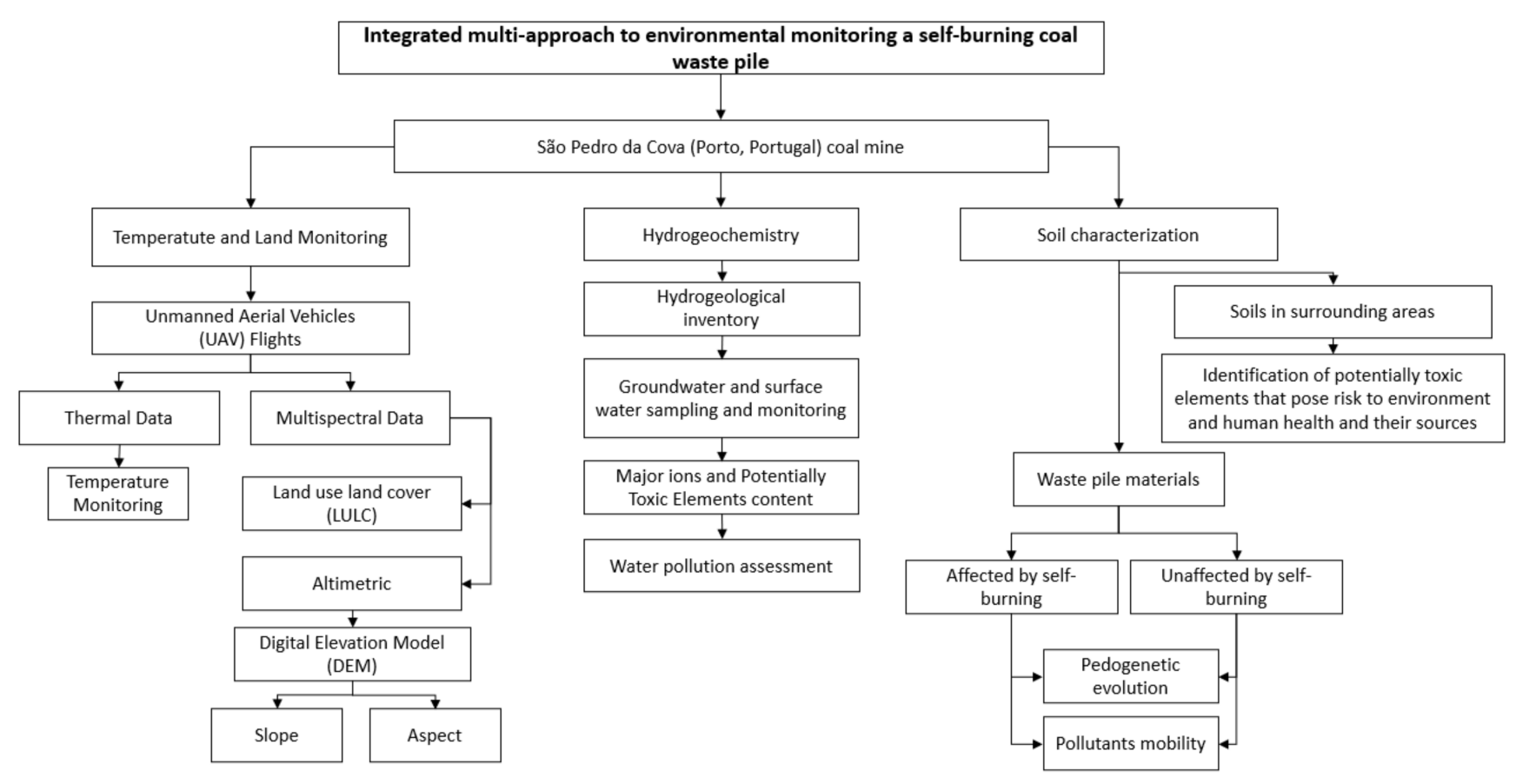

Figure 1. Workflow of the multi-approach followed in this work.

\subsection{Study Area}

The São Pedro da Cova coal mine (lat: $41^{\circ} 09^{\prime} 25^{\prime \prime} \mathrm{N}$; lon: $8^{\circ} 30^{\prime} 06^{\prime \prime} \mathrm{W}$ ) is located in Gondomar, Porto, Portugal, and occupies an approximate area of $28,000 \mathrm{~m}^{2}$. It is situated close to the urban center of São Pedro da Cova, just a few meters from several social infrastructures, and it is surrounded by agricultural fields (Figure 2). The Köppen-Geiger climate classification of the study area is Csb [33].

The study area is part of the Douro Carboniferous Basin (DCB) aged from the Upper Pennsylvanian (Lower Stephanian C) that presents an NW-SE alignment, with an approximate length of $53 \mathrm{~km}$ and a thickness ranging from 30 to $250 \mathrm{~m}$ [34]. The Douro Carboniferous Basin is a coal-bearing sequence deposited in a limnic basin controlled by variations in tectonic activity, resulting in a syntectonic sedimentation. The sedimentary sequence includes a basal breccia, followed by fossiliferous shales, siltstones and sandstones, along with interlayered conglomerates and coal seams exploited in the so-called Douro Coalfield [35] for almost 200 years (until 1972) in the São Pedro da Cova area.

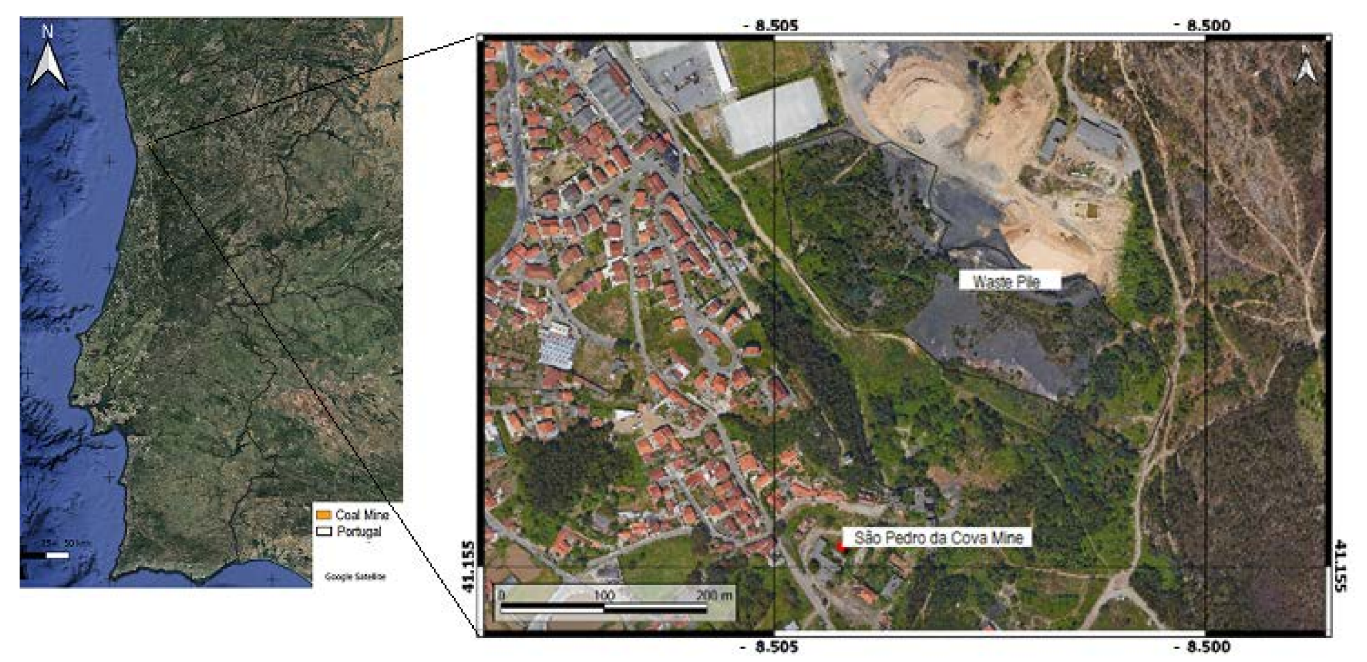

Figure 2. Study area (adapted from [36]). 
The occurrence of coal-related fires in Portugal was identified in five coal waste piles resulting from Douro Coalfield mining activities. Three of the referred coal waste piles, São Pedro da Cova, Lomba and Midões, were emplaced over the old mine sites and adjacent areas and started burning in 2005, after forest fires that caused their ignition [24]. The other two, in the Pejão mining area, were ignited by forest fires in 2017. From the five coal waste piles which were under a self-burning process, only the São Pedro da Cova waste pile is still burning at present.

\subsection{Temperature Monitoring}

Studies using UAVs can be applied to relatively small areas that present heterogeneity in terms of the characteristics to be analyzed, since their spatial resolution can corroborate identifying transition zones in greater detail when compared to a satellite, for example, besides the autonomy to establish the flight plan and the most appropriate altitude [37], within the limits allowed by the legislation.

Coal mine temperature measurements were obtained by a thermal infrared (TIR) sensor and supplemented with field measurements. The acquisition of surface temperature data in situ was performed at specific points with a TIR thermometer, namely, the Electronic Temperature Instruments Ltd. RayTemp 4, which has a 9:1 lens and a fixed emissivity of 0.95. The geographical coordinates of these points were recorded by a Trimble R6 GNSS receiver. Measurements took place at about $45 \mathrm{~cm}$ above the target, culminating in a surface incidence with a diameter of $5 \mathrm{~cm}$.

The five UAV flights conducted at the São Pedro da Cova coal waste pile occurred near 12 p.m. (UTC), i.e., in the solar nadir, in different seasons of the year, in order to evaluate the influence of seasonality on the data. The minimum and maximum air temperatures for the survey days on which thermal collections took place are listed in Table 1.

Table 1. Dates, seasons and respective air temperatures on the flight days.

\begin{tabular}{cccc}
\hline Data & Season & Min. Temperature $\left({ }^{\circ} \mathbf{C}\right)$ & Max. Temperature $\left({ }^{\circ} \mathbf{C}\right)$ \\
\hline July-2019 & Summer & 16 & 20 \\
December-2019 & Winter & 6 & 17 \\
May-2020 & Spring & 13 & 22 \\
August-2020 & Summer & 18 & 26 \\
November-2020 & Autumn & 9 & 19 \\
\hline
\end{tabular}

The flight campaigns were conducted using a Phantom 4 Pro UAV. Thermal data were collected with FLIR Systems' Vue Pro R (TIR sensor), and the Micasense RedEdge was the multispectral sensor used. The flights had an altitude between 100 and $140 \mathrm{~m}$, and a longitudinal and lateral overlay between 70 and $75 \%$. The characteristics of the sensors used are listed in Table 2.

Table 2. Specifications of the UAV sensors used during the campaigns.

\begin{tabular}{cccc}
\hline Parameters & RGB Camera & TIR Sensor & Multispectral Sensor \\
\hline Resolution (MP) & 20 & 0.33 & 1.2 \\
Image size (in pixels) & 5472 by 3648 & 640 by 512 & 1280 by 960 \\
Sensor pixel size $(\mathrm{mm})$ & 0.0026 & 0.017 & 0.00375 \\
Sensor size $(\mathrm{mm})$ & 12.8 by 7.2 & 10.9 by 8.7 & 4.8 by 3.6 \\
Focal length $(\mathrm{mm})$ & 8.8 & 7.5 to 13.5 & 6 \\
Spectral band $(\mu \mathrm{m})$ & $0.4-0.7$ & 113 & $*$ \\
Sensor weight $(\mathrm{g})$ & No data & 180 \\
\hline
\end{tabular}

* The Micasense RedEdge multispectral data were recorded in five different bands (blue, green, red, red edge and NIR). 


\subsection{Altimetric Variations}

The Trimble R6 receiver was used to define the geographic coordinates and altitude of the ground control points (GCPs) in situ, in the World Geodetic System 1984 (WGS84). The definition of these points was critical for both processing and validation of the altimetric values. All the data were generated in the European Terrestrial Reference System 89 (ETRS89)/Portugal Transverse Mercator 2006 (TM06).

For each campaign, a DEM was generated from a photogrammetric processing chain using the internal algorithms of Agisoft Metashape [38]. This program allows the creation of dense point clouds, orthomosaics, digital surface models (DSMs) and digital terrain models (DTMs) from the data recorded by the UAV. As validation, we used the altimetric values calculated by Agisoft compared to those measured in situ (GCPs), in ArcGIS 10.7.1 [39].

The DEM can be used to generate by-products to characterize the studied surfaces, such as aspect and slope, in GIS software. The DEM generation procedures are presented in Figure 3.

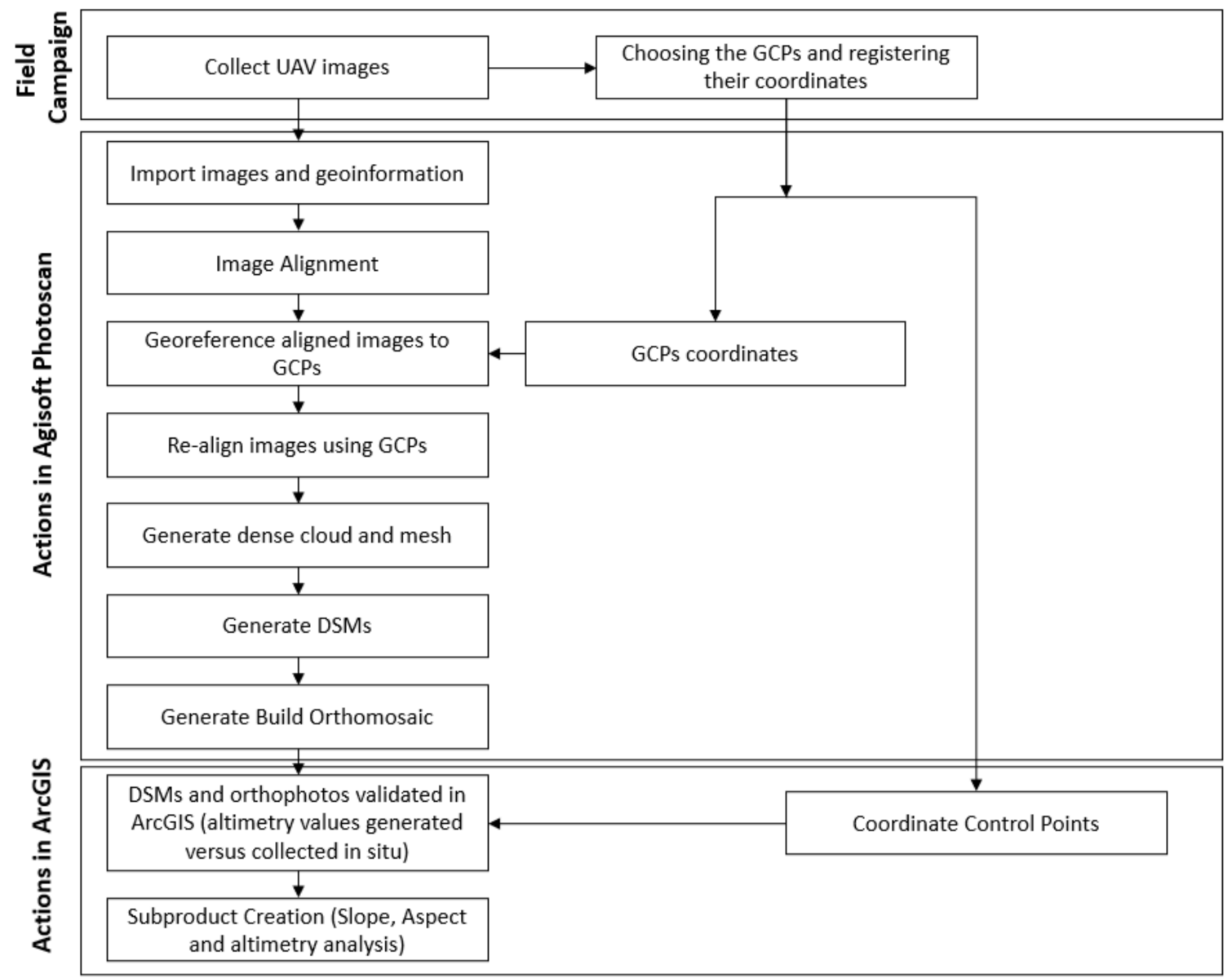

Figure 3. Procedures for DEM generation (adopted from [40]).

\subsection{Land Use Land Cover (LULC)}

From UAV data, and considering image classification algorithms, it is possible to distinguish and classify the classes and elements present on the Earth's surface. This procedure is especially useful for obtaining the land cover of the study area. Image classification can be divided into supervised and unsupervised. Supervised classification corresponds to classifying pixels of an unknown identity by applying a classification algorithm, in which the user indicates training areas whose spectral characteristics are known. In this classification, the user has control over the informed categories and the resulting ones can validate the result with training areas. However, the classifier is conditioned to the 
data provided, which may suppress unidentified/unique classes, and there is a need to know the location in detail [41,42]. Unsupervised classification occurs with the grouping of image pixels based on spectral characteristics, where the number of classes expected can be informed by the user. In this classification, extensive knowledge of the area is not required, and the subjectivity is minimized, compared with supervised classification [43]. However, clustering may define classes of no interest, as there is limited user control of the process, and the relationships between the natural groupings of spectra are not directly correlated in all cases, which may corroborate mixing of distinct classes [41]. In this study, this classification was adopted.

NDVI is used to identify, classify and estimate the biomass of plantations and forests [44-46] and in this work was employed for analyzing the spatial relation of vegetation and temperature. The NDVI value ranges from -1 to 1 (Equation (1)). The highest value represents healthy vegetation, while the lowest NDVI value indicates non-vegetative cover.

$$
\mathrm{NDVI}=(\mathrm{NIR}-\mathrm{RED}) /(\mathrm{NIR}+\mathrm{RED})
$$

where NIR is the near-infrared band and RED is the red band.

\subsection{Hydrogeochemical Characterization}

The hydrogeochemical characterization was performed through the analysis of groundwater and surface water samples, with and without the influence of mine drainage. Water samples were collected over nine campaigns, from April 2017 to December 2019, in five locations: two in Silveirinhos stream, upstream (A1) and downstream (A4) from the mine effluent discharge sites, two in mine drainage galleries (A2 and A3) and one in a spring without mining influence (A5). This set of sampling points provided a monitoring network for investigating water pollution caused by coal mining [47]. The location of the sampling sites is shown in Figure 4.

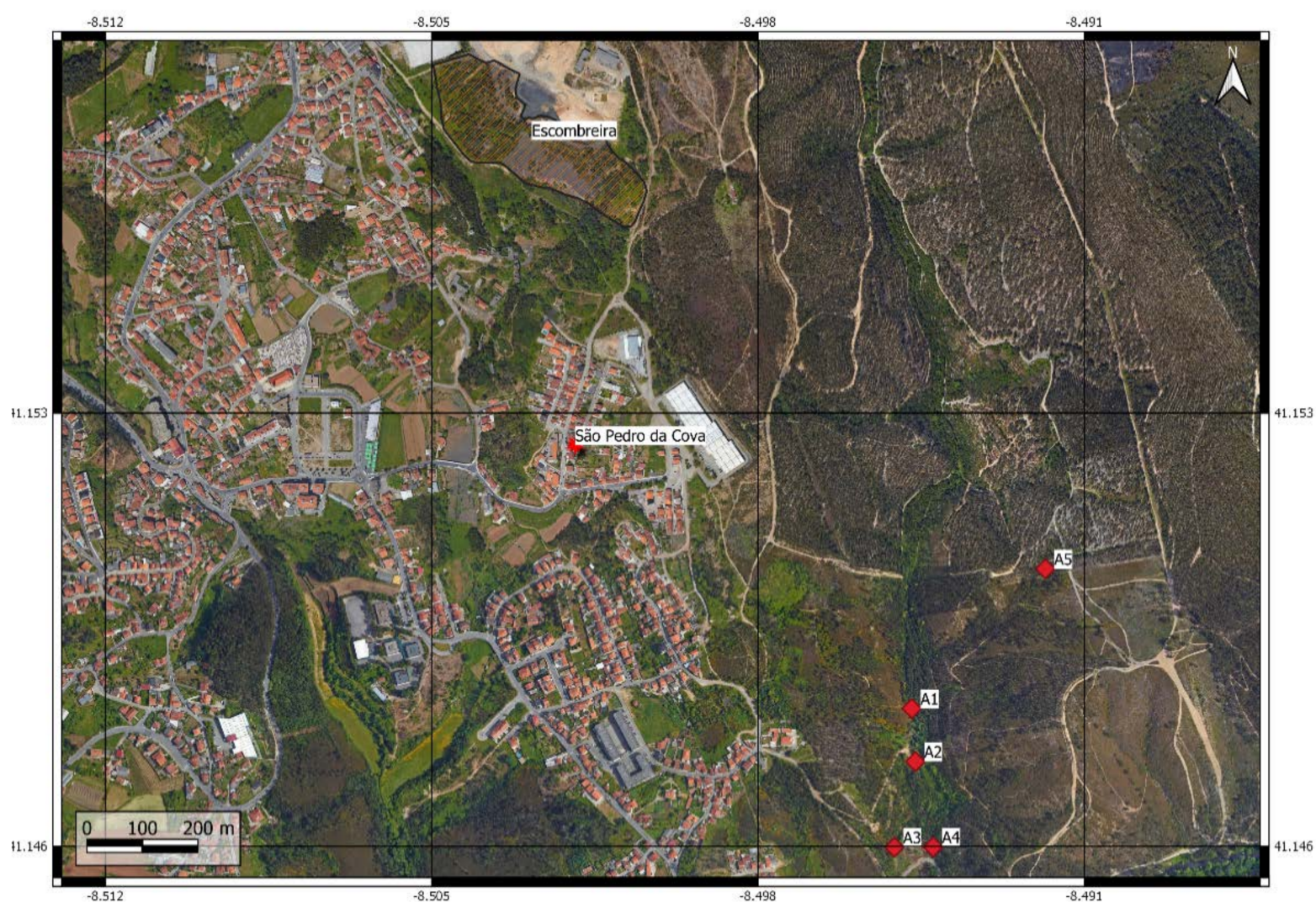

Figure 4. Water samples sites. 
Samples were collected according to ISO 5667-3:2018 and were analyzed for a range of chemical constituents, such as turbidity, total alkalinity, color, total organic carbon (TOC), major ions and metals. Water temperature, $\mathrm{pH}$ and electrical conductivity (EC) were measured in situ with a Hanna Instruments HI991300 device. Analyses were performed according to procedures outlined in Standard Methods for the Examination of Water and Wastewater (SMWW) 23rd edition [48] and in Le Rodier-L'analyse de l'eau 10 édition [49].

Water turbidity was measured in a Hach 2100N Laboratory Turbidity Meter. Total alkalinity, carbonates and bicarbonates were analyzed by titration. Phosphate, color and boron were analyzed in a Shimadzu UV-1601 Spectrophotometer (Shimadzu Corporation, Kyoto, Japan). TOC was analyzed in a Shimadzu TOC-V (TOC-ASI-V, Shimadzu Corporation, Kyoto, Japan). Chemical oxygen demand (COD) was evaluated in a Hach DR 2800 Spectrophotometer (Hach Company, Loveland, CO, USA). Major inorganic ions $\mathrm{Na}, \mathrm{K}$, $\mathrm{Mg}, \mathrm{Ca}, \mathrm{Cl}, \mathrm{NO}_{3}, \mathrm{~F}$ and $\mathrm{SO}_{4}$ were analyzed by ion chromatography (DionexTM system DX-120/ICS-1000, Dionex Corporation, Sunnyvale, CA, USA), metals (Mn, Cu, Cr, As, Ni, $\mathrm{Cd}$ and $\mathrm{Pb}$ ) were analyzed by electrothermal atomic absorption spectrometry according to the SMWW Part 3000-METALS, 3113 method, in a Varian AA240 Atomic Absorption Spectrometer (Varian Inc., Palo Alto, CA, USA), and components such as aluminum, iron, nitrite and ammonia were analyzed in a Continuous Segmented Flow Instrument (San-Plus Skalar, Skalar Analytical, Breda, The Netherlands). The limits of detection of the analytical methods (LD) were: $1.0 \mathrm{mg} / \mathrm{L}$ for COD; 0.3 for TOC; $0.8 \mu \mathrm{S} / \mathrm{cm}$ for EC; $0.2 \mathrm{NTU}$ for turbidity; $0.02 \mathrm{mg} / \mathrm{L}$ for $\mathrm{F} ; 2 \mathrm{mg} / \mathrm{L}$ for $\mathrm{HCO}_{3}$ and $\mathrm{CO}_{3} ; 0.03 \mathrm{mg} / \mathrm{L}$ for $\mathrm{Cl}, \mathrm{SO}_{4}, \mathrm{NO}_{3}, \mathrm{Na}, \mathrm{K}$, $\mathrm{Ca}$ and $\mathrm{Mg} ; 0.01 \mathrm{mg} / \mathrm{L}$ for $\mathrm{PO}_{4} ; 0.001 \mathrm{mg} / \mathrm{L}$ for $\mathrm{NO}_{2}$ and $\mathrm{NH}_{4} ; 0.001 \mathrm{mg} / \mathrm{L}$ for $\mathrm{Mn}, \mathrm{Cd}, \mathrm{As}$, $\mathrm{Pb}, \mathrm{Ni}, \mathrm{Cu}$ and $\mathrm{Cr} ; 0.025 \mathrm{mg} / \mathrm{L}$ for $\mathrm{Fe}$; and 0.05 for $\mathrm{Al}$.

Analytical standards were supplied by Sigma-Aldrich (Steinheim, Germany) and Merck (Darmstadt, Germany), and organic solvents were supplied by Merck (Darmstadt, Germany). Ultrapure water was highly purified by a Milli-Q gradient system $(18.2 \mathrm{~m} \Omega / \mathrm{cm})$ from Millipore (Milford, MA, USA).

\subsection{Soil Characterization}

The soil characterization of the study area followed two different approaches: (i) one was focused on the waste pile materials, including their pedogenetic evolution and the properties of the wastes affected and unaffected by self-burning, both influencing the dissemination of pollutants, and the other approach (ii) focused on the characterization and monitoring of the soils surrounding the mine complex and the waste pile, identifying hazardous soil pollutants that can pose a risk to the environment and human health, accompanying the contamination evolution.

Bearing in mind that the coal waste pile can be a potential source for potentially toxic elements (PTEs) and polycyclic aromatic hydrocarbons (PAHs) leaching [50,51], a hydropedological assessment was conducted in two contiguous locations in the São Pedro da Cova mine waste pile, one representing the waste with a normal pedological evolution and the other representing the waste which has been affected by self-burning. The soil horizons were characterized geochemically, mineralogically, hydropedologically and regarding their leaching capability [52].

The soil monitoring, surrounding the old mine and its waste pile, included two sampling campaigns: the first was conducted at the end of the rainy season, and the second concluded at the end of the dry season. During these campaigns, 50 surface soil samples were collected, over a regular mesh, with approximately $100 \mathrm{~m}$ spacing between samples, covering an area of about $480,000 \mathrm{~m}^{2}$. The sampling grid focused on the surrounding soils, excluding the wastes deposited in the old coal mine waste pile, since these materials had been characterized in previous studies [25-29].

Figure 5 shows the soil sampling program distribution over the area, and its local geology. The sampling was preferentially oriented NE-SW, crosscutting the main drainage basin, located southwest of the waste pile and covering a significant portion of urbanized and forest areas, located upstream and downstream of the mine. The soil geochemistry and 
physicochemical parameters were measured for comprehensive characterization, and to provide useful information for the identification and understanding of the trace elements mobility, providing guidance to recognize the contamination sources and dynamics. The concentrations of trace elements present in soils were compared in the two campaigns, the percentages of difference between elemental concentrations from the first to the second campaign were calculated for each sample point and the spatial distribution of these differences was modeled using ordinary kriging as the geostatistical algorithm $[53,54]$. The spatial analysis of the trace elements' concentration between successive soil surveys was performed in ESRI's software ArcGIS 10.7.1 [39].

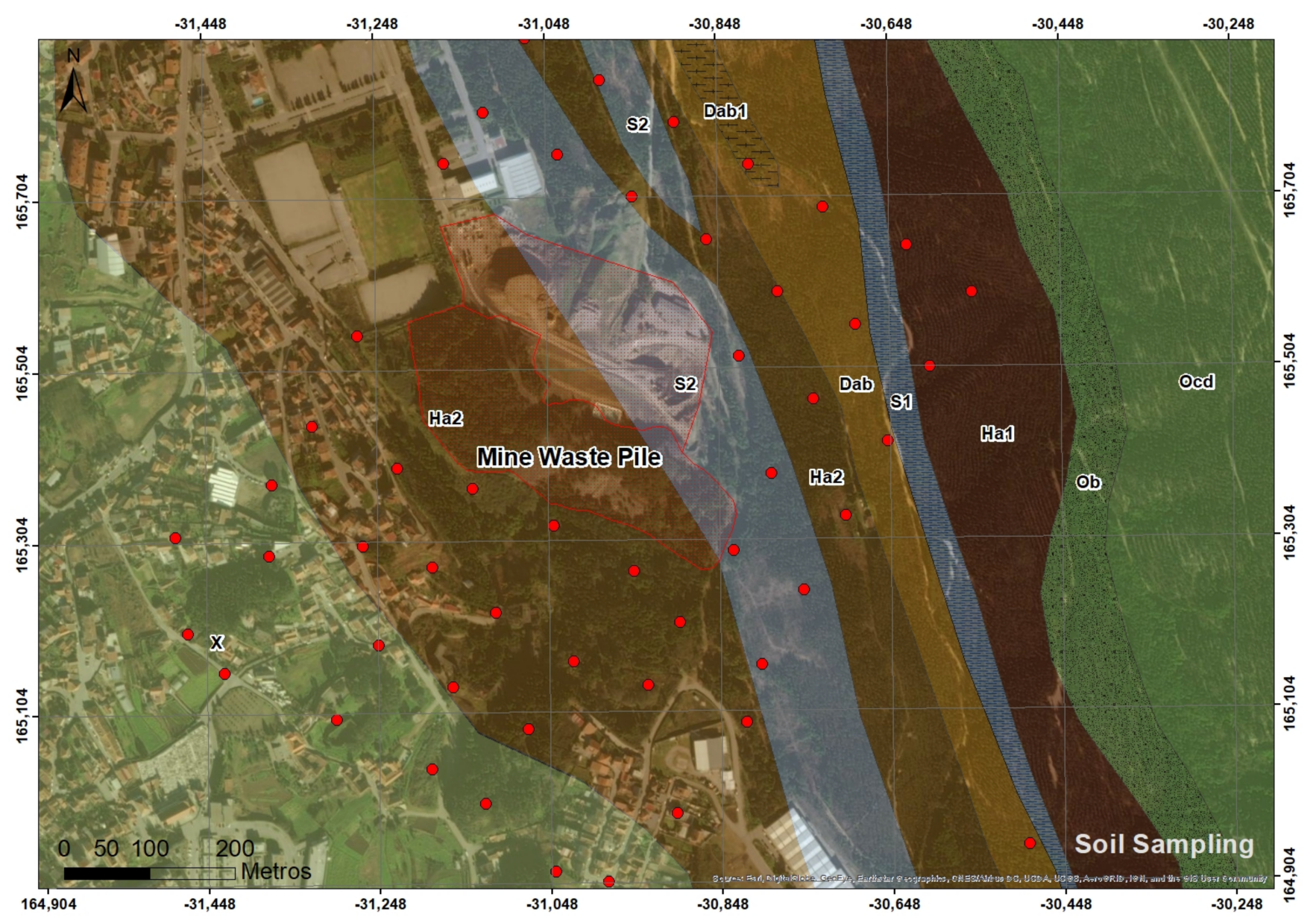

Figure 5. Settings of the sampling grid. Legend: X1-Precambrian and/or Cambrian schists and greywackes; ObOrdovician quartzites with schists intercalations; Ocd-Ordovician shales; S1—Silurian schists with Monograptus; S2Silurian schists, greywackes and quartzites; Dab—Devonian shales and sandstones; Dab1—Devonian quartzites; Ha1— Carboniferous conglomerates, sandstones and micaceous schists; Ha2-Carboniferous conglomerates, arkoses, carbonaceous schists and anthracites.

\subsection{GIS Data Integration}

A GIS open-source application (Coal Mine) was created under QGIS open-source software [55]. Additionally, a PostGIS/PostgreSQL database was created to host all the geospatial information acquired in the scope of this project. The database was connected to the GIS application, allowing the integration, combination and manipulation of the data in the GIS environment. The application was developed under the open source concept, meaning that it respects the Stallman four freedoms: (i) to run the program for any purpose; (ii) to study how the program works, and change it; (iii) to redistribute copies; and (iv) to distribute copies of modified versions [56]. 
The development of such an application presents a relevant advantage in the environmental ecosystem context as it allows improving and optimizing the manipulation of project data and performing the management of former coal mines, improving safety and process automatization. The data from campaigns already conducted are hosted and updated in the database, which can be easily accessed by the intuitive tool. The data incorporated/connected to the Coal Mine application were based in the first campaign (July 2019) concerning the water and soil samples, the temperature points, the temperature raster values and the DEM and LULC, both generated from the data obtained from the first flight. As referred to in the previous sections, thus far, four more campaigns have been performed (December 2019, May, August and November 2020), and these results have been incorporated into the GIS application. In the future, more campaigns will be performed, and the Coal Mine application will be continuously updated with new data.

\section{Results and Discussion}

The main results regarding the multi-approach described above will be presented in the following sections. All the results are being integrated into the GIS application (Coal Mine) to manage all the data and to relate all the environmental variables monitored.

\subsection{Temperature Monitoring}

For each flight campaign (Table 1), a thermal orthomosaic was generated (Figure 6). For comparative temperature purposes, it was necessary to standardize the color scale.

Temperature monitoring allows the identification of an area that consistently presents higher temperatures, with maximums over $50^{\circ} \mathrm{C}$. This area has approximately $200 \mathrm{~m}^{2}$ and is located in the south of the waste pile, near its base. The limits of this highlighted area are consistent with field observations of gas release as a result of self-burning and were validated in situ by a portable infrared thermometer.

In Figure 6, it is possible to compare the surface temperature measured along the waste pile throughout different seasons of the year, and to note the influence of the air temperature and solar incidence on its surface temperature distribution. The August surface thermal map was collected under higher atmospheric temperatures, showing limitations in the identification and definition of the self-burning areas.

Even though the number of campaigns is reduced, a Pearson correlation was performed to identify if the temperature recorded by the thermal sensor on board the UAV was influenced by the air temperature on the day of the flight. To obtain the temperature values at the same location in all the campaigns, 217 points were defined in the waste pile area. The correlation between the data recorded by the thermal sensor on board the $\mathrm{UAV}$ and the air maximum temperature (available from the Instituto Português do Mar e da Atmosfera (IPMA) [57]) in each campaign (because the flights occurred near the solar nadir, i.e., the period of the highest incidence of radiation) was 0.84 , meaning that the air temperature directly influences the waste pile surface temperature.

A complementary analysis was performed considering the slope and aspect of the waste pile. Figure 7 presents the aspect (exposure) maps generated for each of the campaigns. The thermal orthomosaics from May and August, collected on the days that presented the highest atmospheric temperature and sun exposure, showed that the slopes oriented to the southeast were spatially associated with higher temperature patterns. The data collection was achieved in the late morning period when there was greater solar incidence caused by the sun rising to the east of the study area, causing a higher warming in the materials facing this direction. 


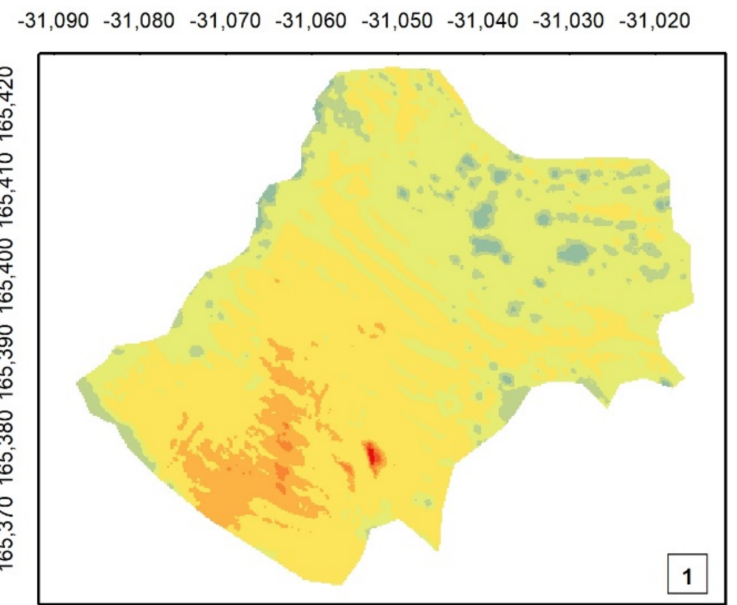

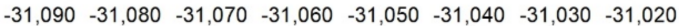

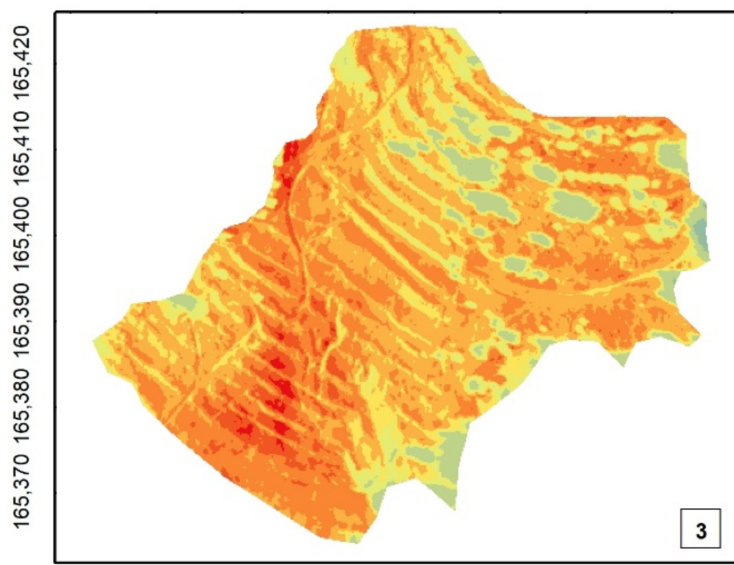

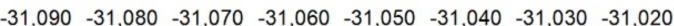
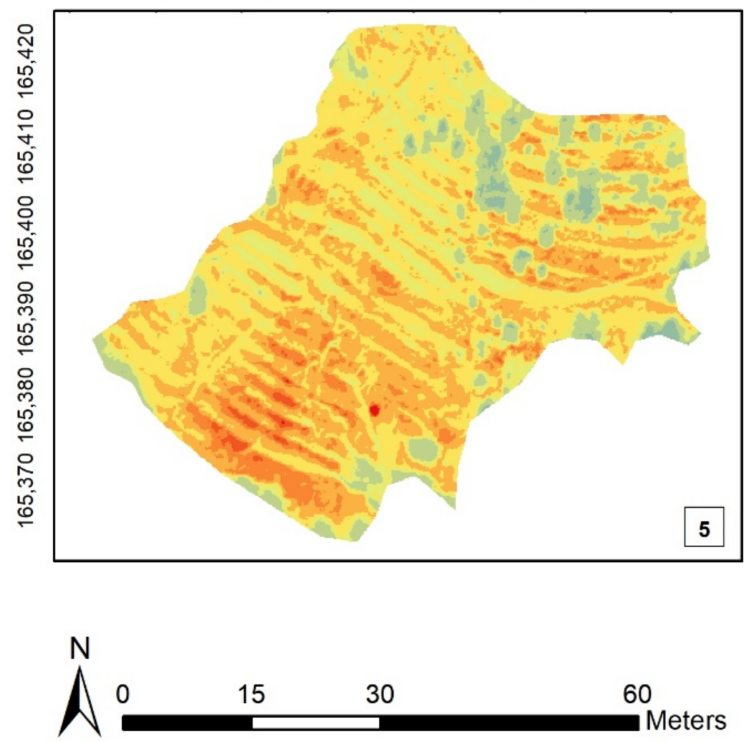

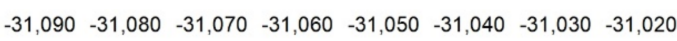

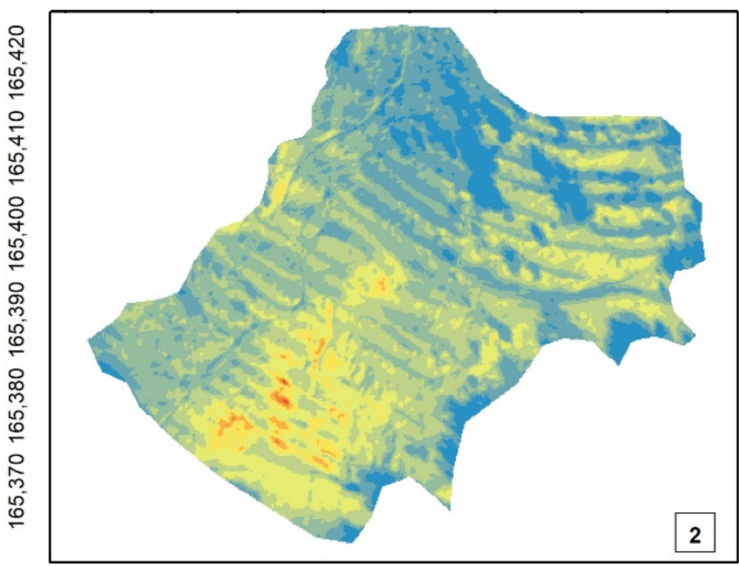

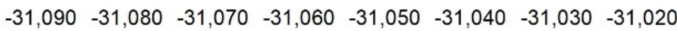

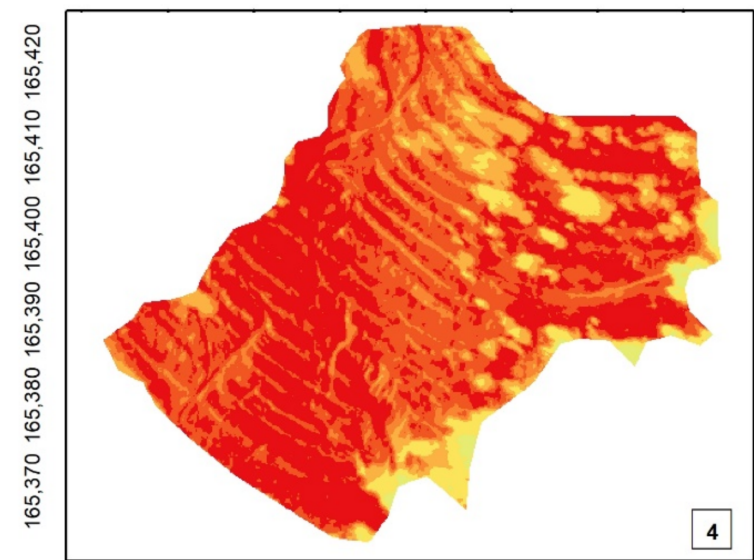

\section{Legend}

Thermal Orthomosaic $\left({ }^{\circ} \mathrm{C}\right)$

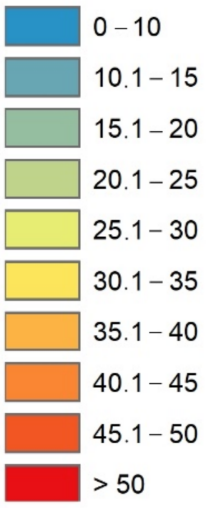

Coordinate System: ETRS 1989 Portugal TM06

Projection: Transverse Mercator

Datum: ETRS 1989

False Easting: 0.0000

False Northing: 0.0000

Central Meridian: -8.1331

Scale Factor: 1.0000

Latitude Of Origin: 39.6683

Units: Meter

Figure 6. Thermal orthomosaic for each campaign $\left({ }^{\circ} \mathrm{C}\right)$ (1-July 2019; 2-December 2019; 3-May 2020; 4-August 2020; 5-November 2020). 


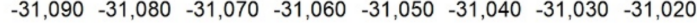

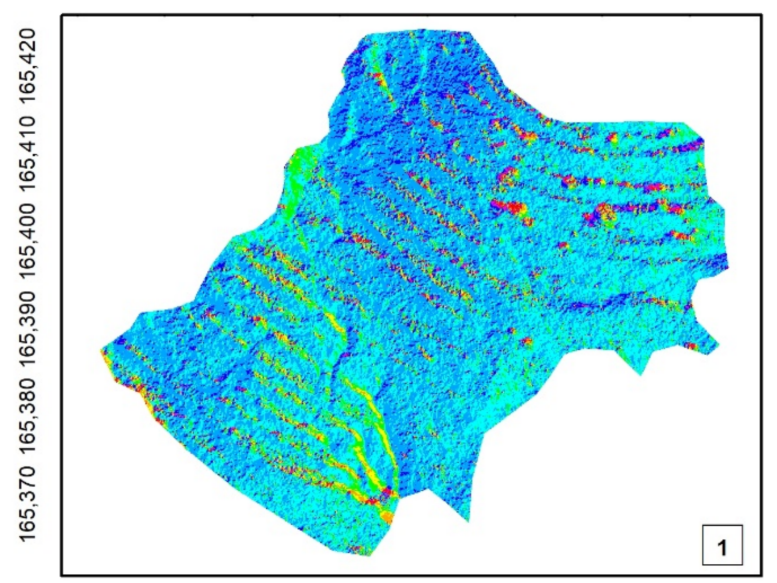

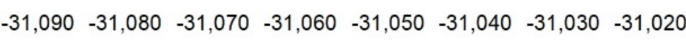

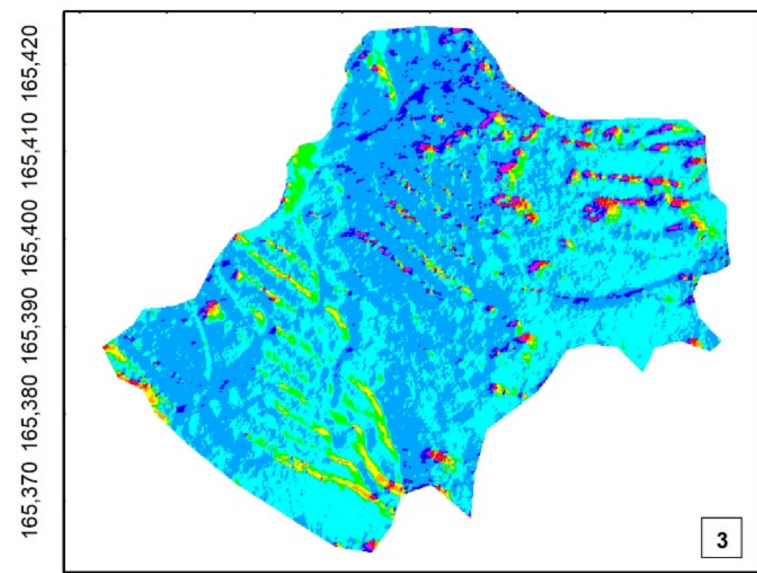

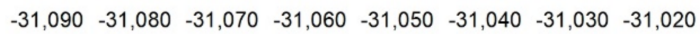
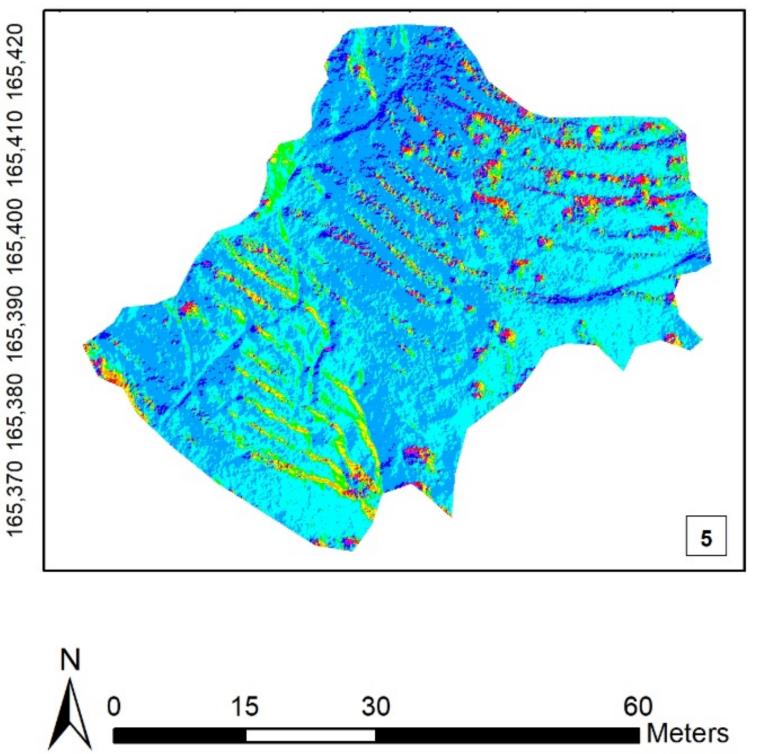

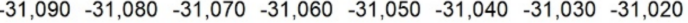

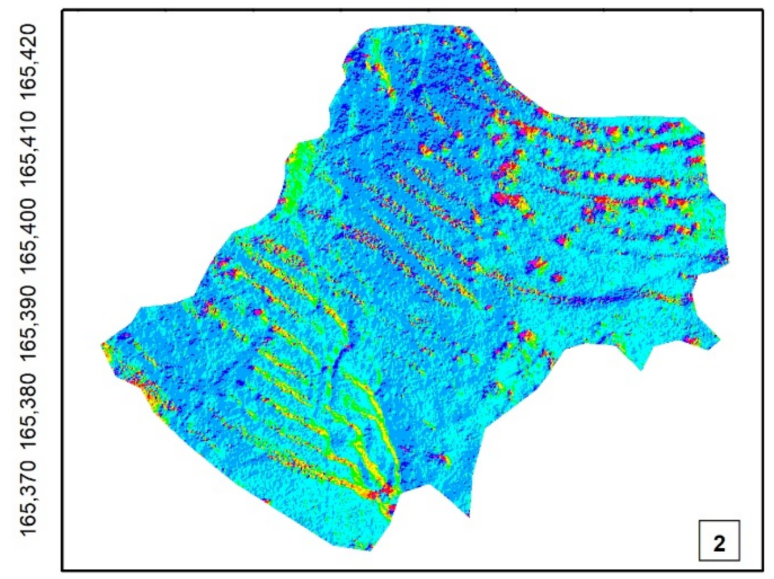

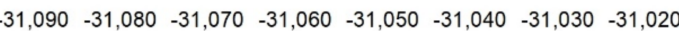

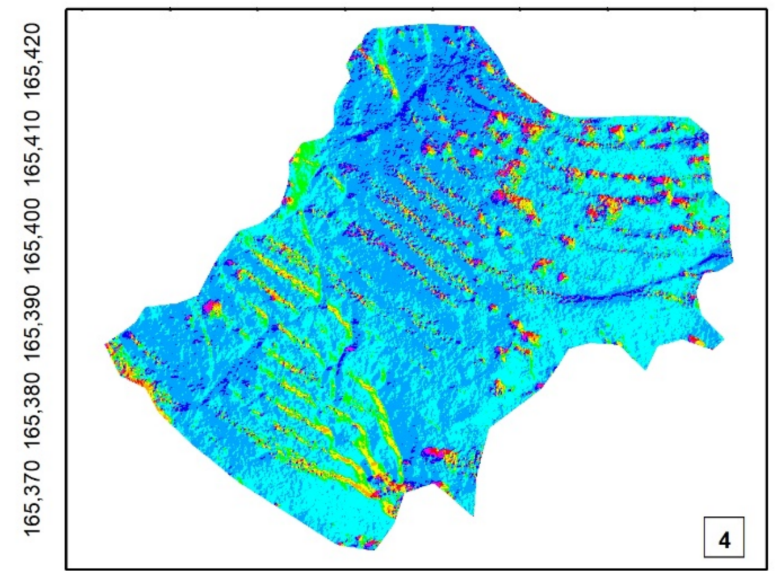

\section{Legend} Aspect (Orientation)

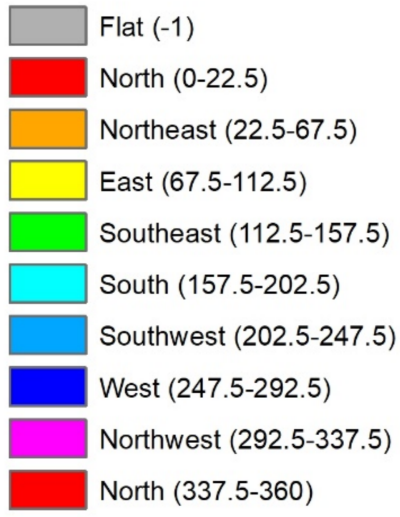

Coordinate System: ETRS 1989 Portugal TM06 Projection: Transverse Mercator

Datum: ETRS 1989

False Easting: 0.0000

False Northing: 0.0000

Central Meridian: -8.1331

Scale Factor: 1.0000

Latitude Of Origin: 39.6683

Units: Meter

Figure 7. Maps of the temperature variation obtained in each campaign (1-July 2019; 2-December 2019; 3-May 2020; 4-August 2020; 5-November 2020). 
It is possible to identify some agreement between the areas with a higher temperature and exposed to the southeast, except for those with vegetation areas, mainly located in the central zone in the upper part of the images. To analyze this relation in more detail, the NDVI (Equation (1)) was computed. Table 3 presents the maximum and minimum NDVI values.

Table 3. NDVI maximum and minimum values.

\begin{tabular}{ccc}
\hline Date & Minimum & Maximum \\
\hline 23 July 2019 & -0.035 & 0.345 \\
7 May 2020 & -0.038 & 0.529 \\
26 August 2020 & -0.025 & 0.533 \\
10 November 2020 & -0.135 & 0.809 \\
\hline
\end{tabular}

The resulting maps were compared to the thermal orthomosaic (Figure 8). In the December campaign, due to equipment unfeasibility, it was not possible to collect the RGB data, and, therefore, it was not possible to generate the corresponding NDVI map. From the results obtained, it is possible to observe an inversely proportional behavior between areas with vegetation and surface temperatures.

The methodology selected to monitor the temperature was effective in an approximate identification and delimitation of the area currently under active burning; however, it can be globally influenced by the atmospheric temperature and sun exposure. Under higher atmospheric temperatures, the waste temperature resulting from the burning process can be masked by the combined effects of sun exposure and the atmospheric temperature, which increase the soil surface temperature externally; as a result, monitoring temperature measurements should be avoided on hot days with intense solar exposure.

\subsection{Altimetric Variations}

In addition to the 217 points already used in the thermal treatment, another 165 points (outside the waste pile, in the surrounding areas) were manually added to the DEM to help in the analysis of altimetric variability, considering stable areas, such as streets and paths [58]. The DEM values of the five campaigns were compared to these points, and the altimetric variation was evaluated. To conduct this evaluation throughout the collection period, the difference between the altimetric values between the first and last campaigns (July, 2019 and November, 2020) was performed, whose results (number of points and percentage) are shown in Table 4.

Considering the altimetric variation analysis, a general decrease in elevation (except for two points) was found. This finding may corroborate the hypothesis that, as selfburning occurs, the material in the waste pile may be reducing. To evaluate this effect quantitatively, the 217 points were separated into four classes, considering the altitude variation scale (Table 5). 


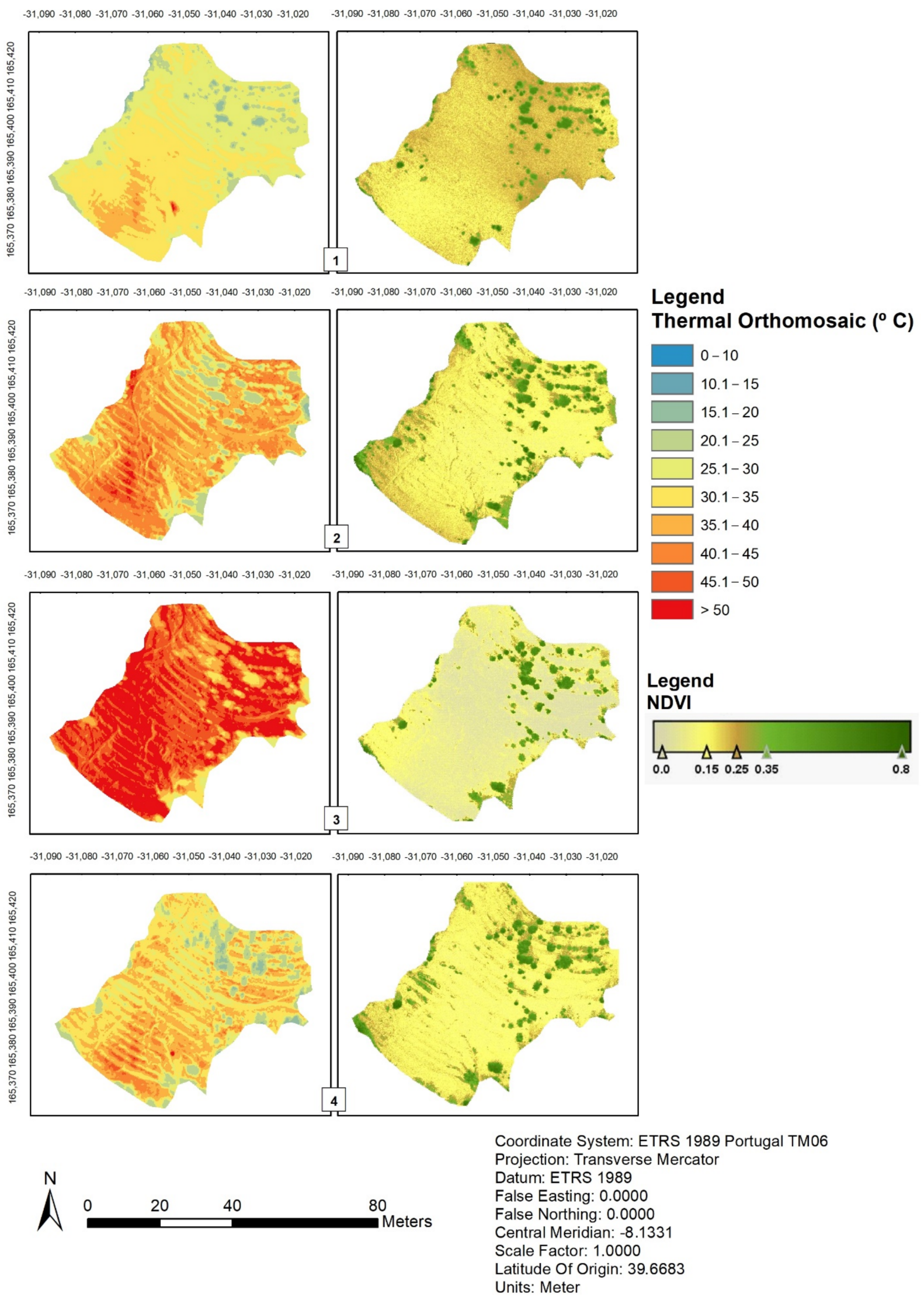

Figure 8. Comparison of temperature $\left({ }^{\circ} \mathrm{C}\right)$ and NDVI, respectively (1-July 2019; 2-May 2020; 3-August 2020; 4-November 2020). 
Table 4. Altimetric differences in the waste pile between the first and last campaigns.

\begin{tabular}{ccc}
\hline Elevation Variation & $\mathbf{N}^{\circ}$ points & $\%$ \\
\hline Kept & 0 & 0.00 \\
Increased & 2 & 0.92 \\
Decreased & 215 & 99.08 \\
\hline Total & 217 & 100 \\
\hline
\end{tabular}

Table 5. Scale referring to the altimetric difference between the first and the last collection.

\begin{tabular}{ccc}
\hline Scale $(\mathbf{c m})$ & $\mathbf{N}^{\circ}$ Points & \% \\
\hline-71.6 to -30 & 57 & 26.27 \\
-29.9 to -20 & 121 & 55.76 \\
$-19,9$ to 0 & 37 & 17.05 \\
$>0$ & 2 & 0.92 \\
\hline Total & 217 & 100 \\
\hline
\end{tabular}

Most of the points $(82.03 \%-178$ points) showed a decrease between 20 and $71 \mathrm{~cm}$. Only two points showed an increase between 10 and $60 \mathrm{~cm}$ (points 24 and 213). Figure 9 shows the geographical distribution of the points in the respective altimetric variability scales. The two points that presented an altimetric increase are circled in blue.

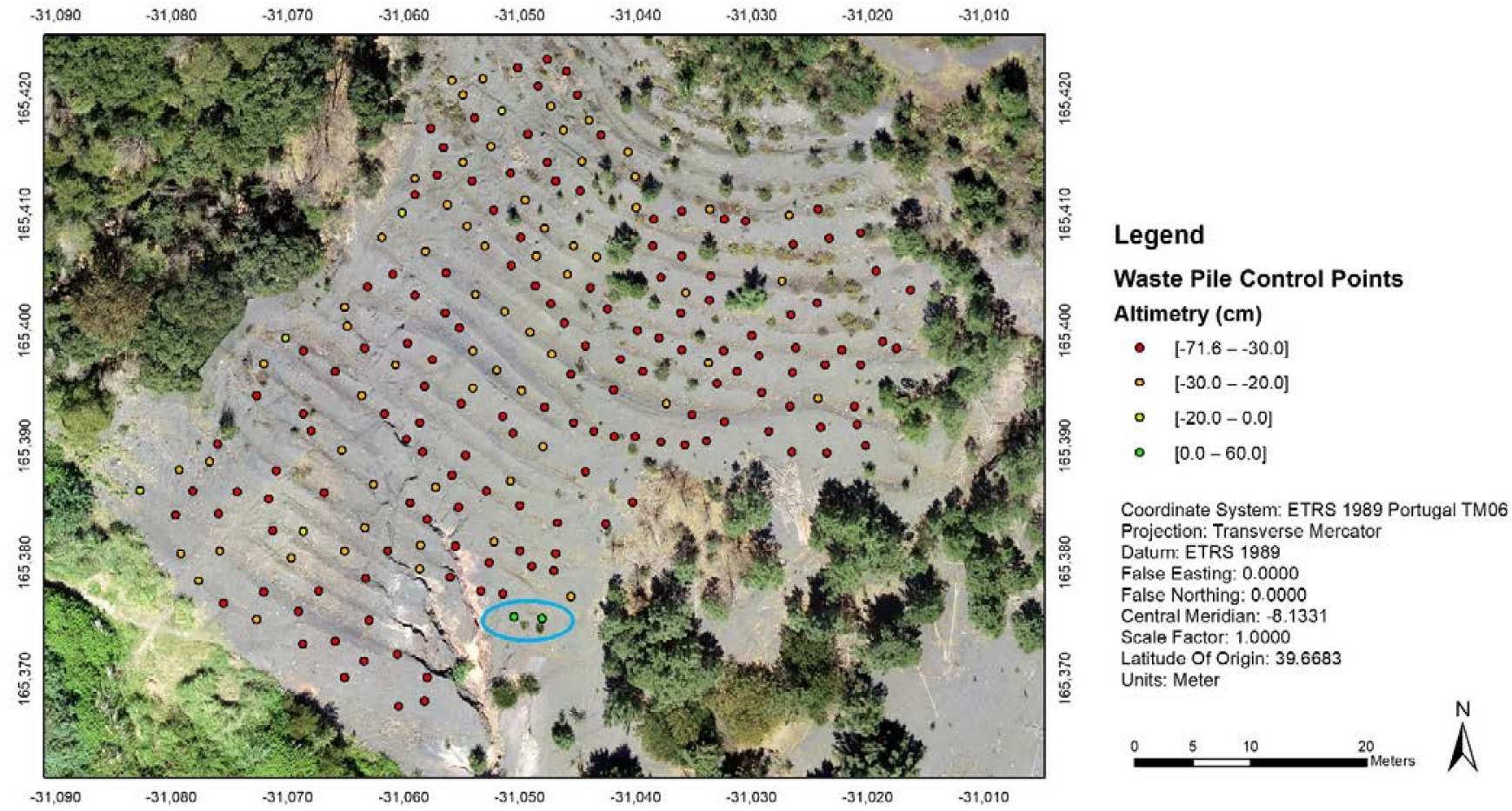

Figure 9. Geographical representation of the altimetric variation.

For the two points that presented an increase in altimetry, a more detailed analysis was carried out to identify the possible cause of this distinct behavior. These two points are located at the base of the waste pile. The main cause for this elevation increase could be related to material that slides down to the waste pile and is deposited in this area. 


\subsection{Land Use Land Cover (LULC)}

The Micasense RedEdge multispectral sensor recorded data in five different bands (blue, green, red, red edge and NIR). These data allowed computing an unsupervised classification to identify the classes presented in the waste pile. The k-means algorithm was used in SNAP software [59], which classifies $n$ observations among $k$ groups, where each datum is grouped to the values closest to the group average, resulting in a spatial division, following the logic of a Voronoi diagram [60]. The k-means algorithm belongs to the partitioning clustering methods in which the mean value of the objects or observation in a cluster is used as the center of the cluster, which is also regarded as the center of gravity for a cluster. The $\mathrm{k}$ parameter is the total number of clusters to create. The general approach for clustering with the k-means algorithm is regarded as an iterative relocation technique. The objective of the algorithm is to improve the quality of the initial cluster. It implies that cluster membership is changed to find the local optima. The clustering or object criterion $(E)$ is to minimize the Euclidean sums of squared deviations of objects from the cluster mean [61].

Considering that the study site does not present great variability in relation to the LULC, the algorithm firstly identified three classes (two classes associated with soil and one with vegetation). However, in a deeper analysis, it was found that the two soil classes are identical, and this discrimination was possibly due to acquisition characteristics (such as sensor angle, shadow effects and light incidence). Therefore, these two soils classes were merged into one soil class, as illustrated in Figure 10.

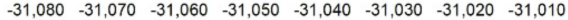

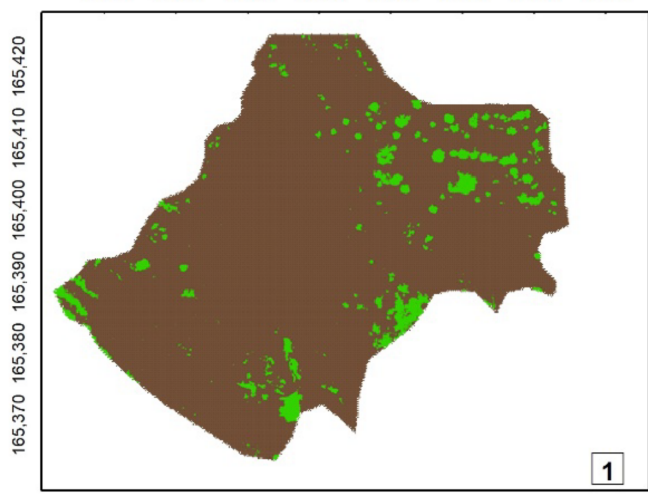

$\begin{array}{llllllll}-31,080 & -31,070 & -31,060 & -31,050 & -31,040 & -31,030 & -31,020 & -31,010\end{array}$

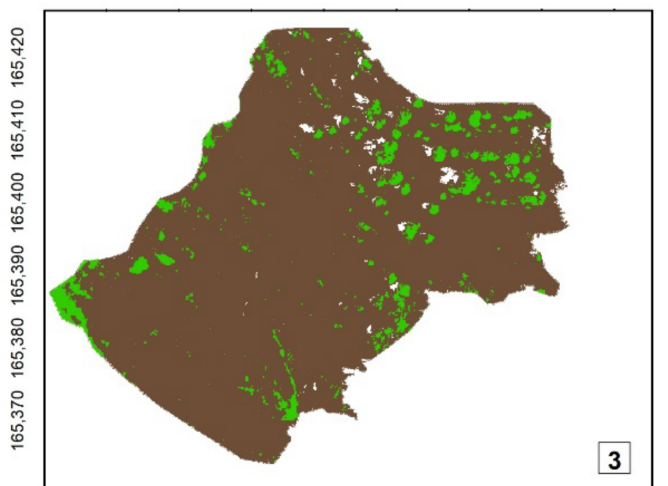

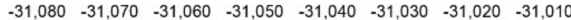

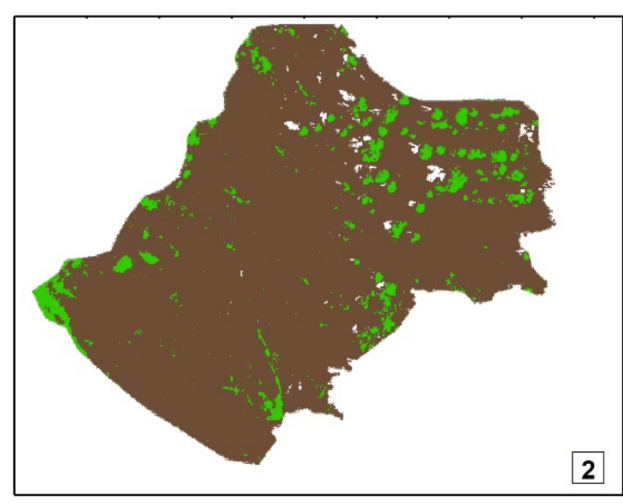

$\begin{array}{llllllll}-31,080 & -31,070 & -31,060 & -31,050 & -31,040 & -31,030 & -31,020 & -31,010\end{array}$

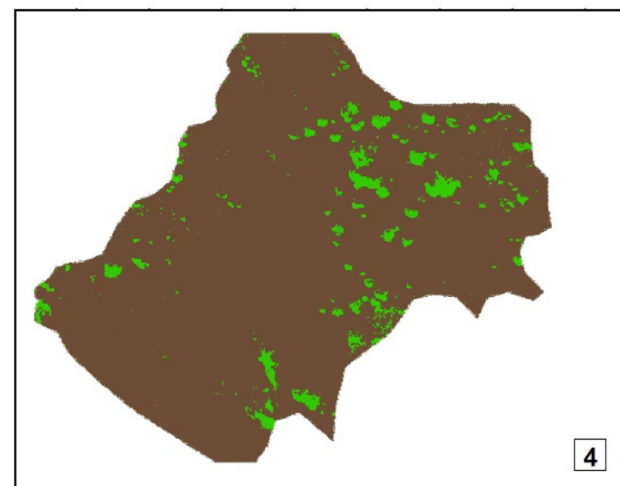

Legend

K-means classification 2 classes

Class identification

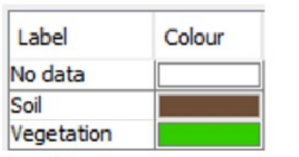

Coordinate System: ETRS 1989 Portugal TM06 Projection: Transverse Mercator Datum: ETRS 1989

alse Easting: 0.0000

False Northing: 0.0000

Central Meridian: -8.133

Scale Factor: 1.0000

atitude Of Origin: 39.6683

Units: Meter

N

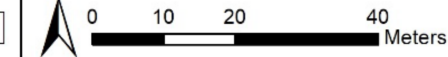

Figure 10. Unsupervised classification considering the k-means algorithm: RGBNIR composition (1-July 2019; 2-May 2020; 3-August 2020; 4-November 2020). 
The seasonality of vegetation, which is directly related to the season of the year, associated with the efficiency of the classifier, allowed distinguishing areas of vegetation, in the bottom and at the top of the waste pile. Furthermore, comparing the results presented in Figure 8, a relationship can be observed between the NDVI, LULC and temperature. The areas classified as vegetation (higher NDVI values) correspond to the areas with a lower temperature in all the images, corroborating the complementation of the analysis and characterization of the LULC.

\subsection{Hydrogeochemical Characterization}

The hydrogeochemical features of water affected by coal mining (A2, A3 and A4) are clearly distinct from water free from such influence (A1 and A5).

Mining effluents are hard in nature, with EC mean values higher than $800 \mu \mathrm{S} / \mathrm{cm}$, as a result of the high concentration of inorganic dissolved solids, metals and metalloids (As, $\mathrm{Fe}, \mathrm{Mn}$ and $\mathrm{Al}$ ). Fe and Mn, with mean concentrations above 50,000 $\mu \mathrm{g} / \mathrm{L}$ and $4000 \mu \mathrm{g} / \mathrm{L}$, respectively, justify the presence of precipitation deposits in the stream affected by mine drainage. Samples collected in A4 are a mixture of surface water and mining effluents, presenting an EC mean value around $500 \mu \mathrm{S} / \mathrm{cm}$ and concentrations of Fe and Mn around $29,000 \mu \mathrm{g} / \mathrm{L}$ and $2900 \mu \mathrm{g} / \mathrm{L}$, respectively, also far above the legal limits for domestic and agricultural purposes $[62,63]$.

Samples without the influence of mine drainage (A1 and A5) have EC below $90 \mu \mathrm{S} / \mathrm{cm}$, significantly lower than the values recorded in the polluted waters.

$\mathrm{EC}$ and $\mathrm{SO}_{4}$ are good indicators of pollution by coal mine effluents and are normally closely related since EC is very sensitive to the presence of sulfate ions. The high concentration of $\mathrm{SO}_{4}$ observed at points $\mathrm{A} 2, \mathrm{~A} 3$ and A4 (between 200 and $400 \mathrm{mg} / \mathrm{L}$ ) contrasts with the concentrations observed in A1 and A5 (below $15 \mathrm{mg} / \mathrm{L}$ ) and may be related to the oxidation of pyrite and, possibly, arsenopyrite in the rock massif affected by coal mining. EC and $\mathrm{SO}_{4}$ are extremely sensitive to the influence of mine drainage, even when large dilutions occur. Unlike other ions, $\mathrm{SO}_{4}$ is not removed by processes of sorption and precipitation, remaining stable even if water $\mathrm{pH}$ varies. This parameter can also be used to predict the approximate concentrations of metals when $\mathrm{pH}$ values are within their solubility limits [64].

The water $\mathrm{pH}$ values, including mine effluents, are relatively constant over time, ranging from 6.0 to 6.5 , being classified as neutral to nearly neutral or slightly acidic waters according to Morin and Hutt (2001) (pH between 6 and 9 to 10) [65].

The concentrations of $\mathrm{Ca}, \mathrm{Na}$ and $\mathrm{Mg}$ are higher in mining drainage areas than in natural water courses. Their presence is due to the conditions inside the mines that are conducive to water-rock interaction and promoted by the particular chemical characteristics of these waters.

The mine effluents' hydrogeochemical facies reflect the circulation paths and waterrock interaction processes which take place in the coal mine. Specifically, mine effluents (A2 and A3) present a typical Mg-SO4 facies, and water from the Silveirinhos stream downstream of the mine effluent discharge (A4) presents a $\mathrm{Mg}-\mathrm{SO} 4 / \mathrm{HCO} 3$ facies. On the other hand, groundwater without mining influence (A5) has a $\mathrm{Na}-\mathrm{Cl}$ facies, while water upstream of discharges (A1) has an intermediate $\mathrm{Na} / \mathrm{Mg}-\mathrm{SO}_{4} / \mathrm{Cl}$ facies [36].

The physicochemical and hydrogeochemical features of the mine effluents observed in A2 and A3 drainage galleries point to deep groundwater circulation in the exploited massif and to significant water-rock interaction. Additionally, the occurrence of groundwater pollution originating from rainwater infiltrating and percolating in the waste pile vadose zone is not clear and is probably residual or even inexistent. Therefore, the main source of water pollution expressed by major ions, PTEs and Fe content seems to be the mine drainage in pores, fractures and galleries of the exploited massif.

The overall quality of groundwater from the drainage galleries (A2 and A3), as well as surface water from the Silveirinhos stream (A4) downstream of the mine effluent discharge 
sites, can be classified as poor, and these waters should not be supplied for human activities, namely, domestic consumption (e.g., drinking, food preparation, bathing) and agriculture.

This component of the research represents a contribution to the understanding of the regional impact of coal mine drainage on water resources. In order to improve the knowledge on this subject in future studies, new sampling campaigns should be carried out in an extended monitoring network.

\subsection{Soil Characterization}

The waste pile characterization in areas affected and unaffected by self-burning pointed to differences regarding soil geochemistry, mineralogy, morphological features of the soil profile and unsaturated hydraulic conductivity. Self-burning caused severe changes in the hydropedological setting, originating great contrasts in the leaching susceptibility of PTEs in different zones of the São Pedro da Cova coal mine waste pile [52]. The study focused on the waste pile identified the most abundant PTEs in the coal wastes as $\mathrm{Cr}$, As and $\mathrm{Pb}$, while $\mathrm{Zn}$ and $\mathrm{Mn}$ prevailed in the leachates [52].

The characterization of soils surrounding the waste pile and the old mine facilities comprehending their geochemical characterization allows the identification and quantification of hazardous soil pollutants in the study area. The results from the two soil geochemical campaigns were identical, with the average concentrations of the trace elements being similar in both (Figure 11). Nonetheless, from the first campaign, at the end of the rainy season, to the second campaign, at the end of the dry season, there was a generalized trend for soils to maintain or moderately reduce the concentrations of trace elements, with exceptions for $\mathrm{Pb}$ and $\mathrm{Zn}$, which suffered a small increase.

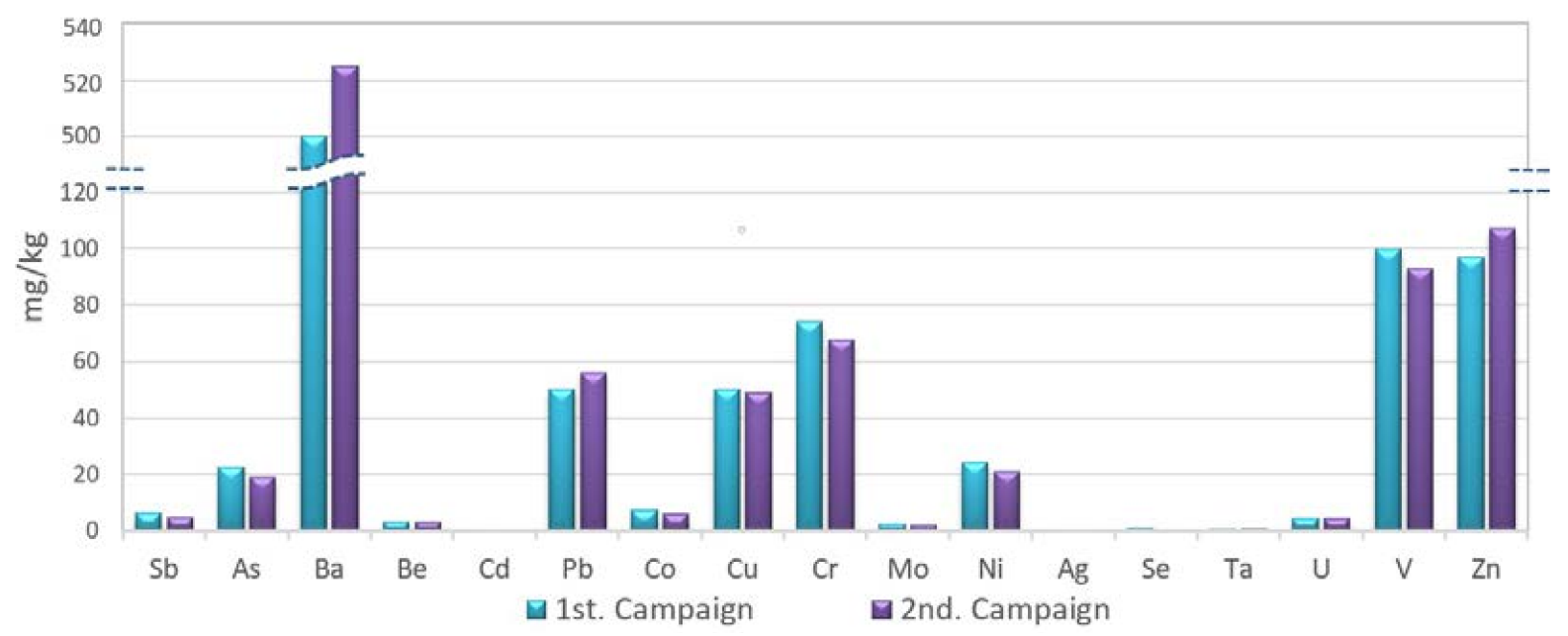

Figure 11. Average trace element concentrations in the soils $(\mathrm{mg} / \mathrm{kg})$ from two sampling campaigns.

The results from the soil sampling campaigns were compared with Portuguese reference values suggested by Agência Portuguesa do Ambiente (APA—the Portuguese Environmental Agency) for agricultural soils [66,67]. The choice of comparing the soil analytical results with agricultural soil reference values was based on the fact that the community that surrounds the mine still practices subsistence farming; therefore, a conservative approach was thought to be more adequate. Figure 12 compares the percentage of contaminated soil samples in both campaigns based on the APA reference values [63] and shows that several trace elements, particularly $\mathrm{Sb}, \mathrm{Ba}, \mathrm{U}, \mathrm{As}, \mathrm{V}, \mathrm{Be}, \mathrm{Cr}, \mathrm{Mo}, \mathrm{Pb}$ and Se, exceeded the threshold values proposed for soil contamination in agricultural areas of $1.0 \mathrm{mg} / \mathrm{kg}(\mathrm{Sb}), 210.0 \mathrm{mg} / \mathrm{kg}$ (Ba), $1.9 \mathrm{mg} / \mathrm{kg}(\mathrm{U}), 11.0 \mathrm{mg} / \mathrm{kg}(\mathrm{As}), 86.0 \mathrm{mg} / \mathrm{kg}(\mathrm{V}), 2.5 \mathrm{mg} / \mathrm{kg}(\mathrm{Be}), 67.0 \mathrm{mg} / \mathrm{kg}(\mathrm{Cr})$, $2.0 \mathrm{mg} / \mathrm{kg}(\mathrm{Mo}), 45.0 \mathrm{mg} / \mathrm{kg}(\mathrm{Pb})$ and $1.2 \mathrm{mg} / \mathrm{kg}$ (Se), respectively, both upstream and downstream of the waste pile, in both campaigns. From the first to the second campaign, the number of contaminated samples tended to decrease, except in the case of $\mathrm{Pb}$ and $\mathrm{Ta}$. 


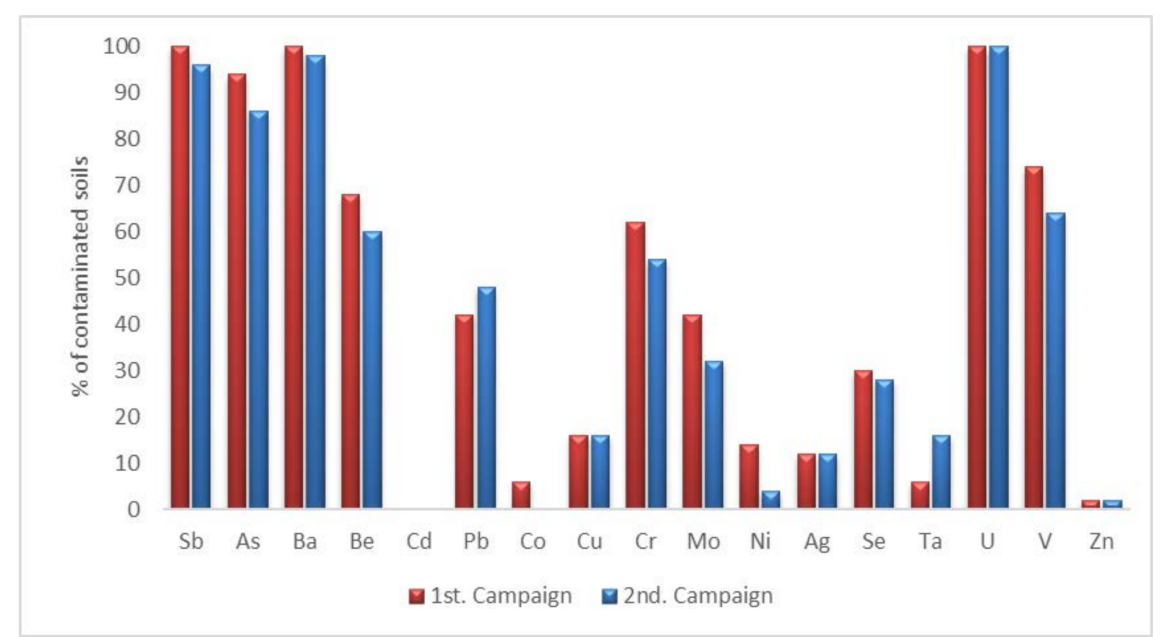

Figure 12. Contaminated soil samples according to the reference values proposed by the Portuguese Environmental Agency, for agricultural soils [67].

Geostatistical algorithms, namely, ordinary kriging, were used to model the concentration differences of trace elements between the two surveys, in the study area. The spatial distribution analysis of the percentage difference on elemental concentrations provides a good insight into the areas that suffered an addition or depletion of some elements over time, contributing a better understanding of the contamination evolution and dynamics.

Figure 13 represents the concentration differences between the first and second soil geochemical surveys, for the trace elements that presented higher contamination rates in the studied samples, namely, $\mathrm{Sb}, \mathrm{Ba}, \mathrm{As}, \mathrm{U}$ and $\mathrm{V}$.

Despite the fact that nearly all samples present values above the reference values for these elements, comparing both soil campaigns, Ba and $U$ do not express a significant concentration change. This may be indicative of a stable or slow contamination process.

The concentration difference resulting from the two campaigns shows a generalized trend to maintain or reduce the $\mathrm{Sb}$ concentration, mostly in forest areas, with the exception of small scattered areas that registered an increase in concentration. These localized concentrations occurred both in urban areas and forests and were always upstream of the mine waste pile. The randomness of the distribution does not seem to show a clear trend and may be related to isolated soil heterogeneities.

East of the study area, in forest areas mostly upstream of the mine, As tends to maintain its concentration, or it moderately decreases, while to the northwest, an area is highlighted, suffering an increase of over $80 \%$ from the first to the second campaign. This area is located in an urban agglomerate, located mostly upstream of the waste pile and its drainage basin. There is no clear influence from the mine waste piles in the As concentration increase. Similarly, $\mathrm{Pb}, \mathrm{Mo}, \mathrm{Cu}, \mathrm{Zn}, \mathrm{Co}, \mathrm{Ni}$ and $\mathrm{Ag}$ also show weak to moderate increasing concentration patterns in the urban areas to the west of the study area, consistent with anthropogenic urban and industrial pollution [68,69].

The trace elements $\mathrm{V}, \mathrm{Be}$ and $\mathrm{Cr}$ present a concentration area inside the waste pile drainage basin, located contiguously to the wastes, which can vary between 20 and $40 \%$ in the case of Be and between 40 and $60 \%$ in the case of $\mathrm{Cr}$ and which can reach $80 \%$ in the case of $\mathrm{V}$. The elements $\mathrm{Cr}$ and Se show another anomaly, with concentration increases higher than $80 \%$, inside the drainage basin, located approximately $350 \mathrm{~m}$ downstream of the waste pile. The elements $\mathrm{V}, \mathrm{Be}$ and $\mathrm{Cr}$ are present in significant quantities in the deposited wastes [70], pointing to an accumulation caused by mine leaching. The increasing concentrations trends of Se can be comparable with patterns observed in the south of the study area by $\mathrm{Cr}$, with $\mathrm{V}$ showing a similar spatial distribution. 

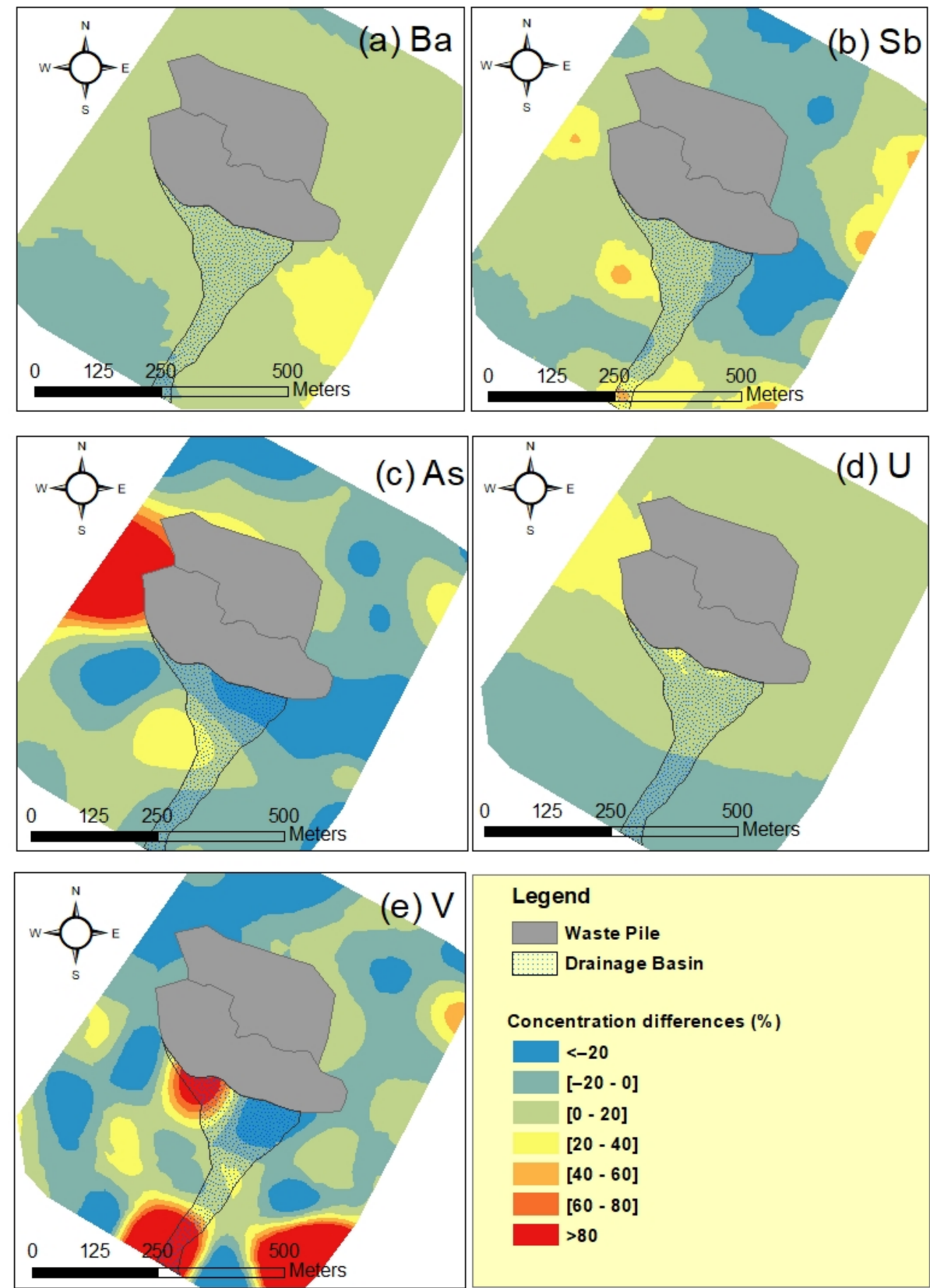

Concentration differences (\%)
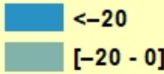

[0 - 20]

[20 - 40]

[40 - 60]

[60 - 80]

$>80$

Figure 13. Differences in elemental concentrations of $\mathrm{Ba}, \mathrm{Sb}, \mathrm{As}, \mathrm{U}$ and $\mathrm{V}$, between the first and second soil geochemical surveys (achieved by ordinary kriging).

The contamination rates for Ta are relatively low, as only $6 \%$ and $16 \%$ of the total soil samples exceeded the threshold proposed for agricultural soils [67] in the successive surveys; however, they registered an increase in the number of contaminated samples with time. Spatially, the Ta concentration increase is placed on the eastern limit of the waste pile drainage basin, extending to a forest area that is locally affected by small waste mine deposits, pointing to an accumulation potentiated by leaching from the mine wastes, as Ta is an element present in these wastes and frequently present in coals [70-72].

The cadmium concentration in the sampled soils is very low, and none of the soil samples exceeded the threshold reference values proposed for agricultural soils.

The different approaches to soil characterization allowed not only describing the material deposited on the waste pile and defining its contamination potential but also monitoring the soils around the mine, classifying their contamination rates and evaluating preferential areas of concentration or depletion of pollutants. Despite the fact that $\mathrm{Ba}, \mathrm{U}$, 
As and Sb show significant contamination rates [67], this approach does not show a spatial relation between the areas that suffered a concentration increase and the mine wastes. On the contrary, $\mathrm{V}, \mathrm{Be}, \mathrm{Cr}$ and Ta may be suffering concentration increases as the result of pollutant transportation from the mine wastes.

\subsection{GIS Data Integration}

The PostGIS 3.0 relational database is an extension of PostgreSQL 12.1 [73]. It was used to store the information acquired in the field. The database includes data from water and soil analysis, metadata of the raster files, temperature measurements (points and raster files), elevation information (DEM) and LULC. The database was connected to the developed GIS application. The Coal Mine application was created using the Python programming language, QGIS application programming interface (API) and Qt API methods [55]. It consists of a button that opens the main window composed of seven menus: File, Water, Soil, Temperature Points, Temperature Maps, Digital Elevation Model (DEM) and Land Use Land Cover (LULC). Basic and standard tools such as Zoom in/out and Pan, a table of contents (Layers) and the canvas complemented the application [55].

Figure 14 presents the graphical interface of Coal Mine with overlapped information related to the thermic orthomosaic, the contour layer from 2019, the contour layer from 2020 and the points with the altimetric variations. Besides the menus to open the different layers, a table of contents is provided with an overlapping order (column on the left).

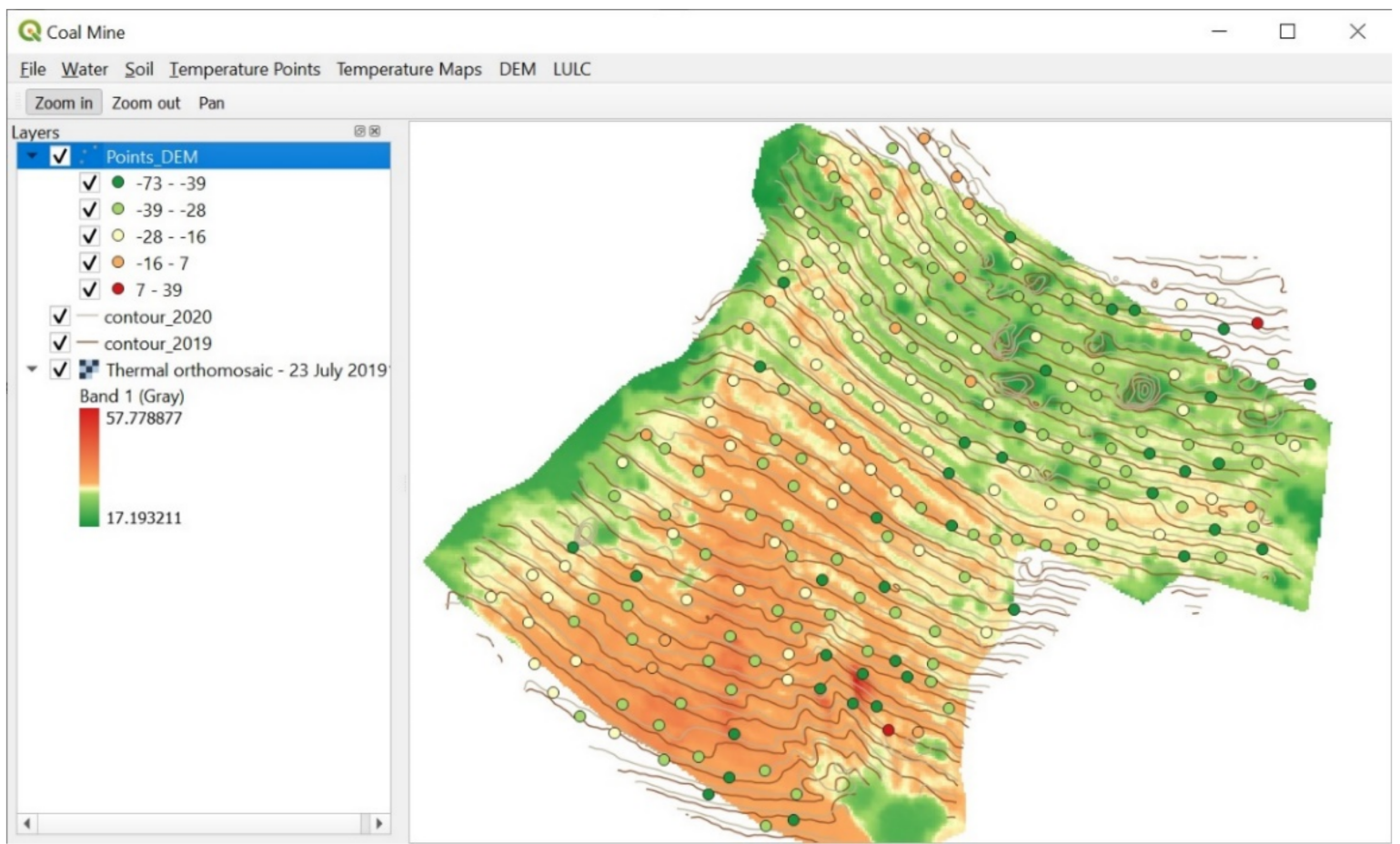

Figure 14. Coal Mine application with overlapped information (raster and vector formats) of the waste pile: thermic orthomosaic, points with DEM values differences, contour from 2019 and contour from 2020.

Each menu connects automatically to the database (where the data are hosted), filters the request and presents the results in the canvas. Different options are provided in each menu: (i) the possibility to open a specific campaign by date, in soil and water campaigns, for instance; (ii) provides interpolation algorithms such as kriging or inverse distance weighting (IDW) to create continuous surfaces, e.g., in temperature measurements; (iii) allows opening raster files (such as DEM) already created; (iv) allows creating slope and aspect maps (from DEM); (v) provides the possibility to open an LULC already created or to apply the k-means unsupervised classification method [52]. The database is continuously updated with new information. This is one of the greatest advantages of being connected 
to the PostGIS database. When the database is updated, the information is automatically incorporated into the Coal Mine application. The data from campaigns relative to water, soils and temperature were incorporated in the GIS application so the user can access the information and compare the data regarding the different campaigns. Additionally, the DEMs created from UAV campaigns were incorporated, as well as the LULC maps. The GIS application is dynamic and allows users to easily access the data in the form of dynamic maps to combine them. The application code is hosted in GitHub, and it is available at https://github.com/liaduarte/Coal-Mine-Project.git (accessed on 30 April 2021).

\subsection{Contribution of an Integrated Multi-Approach for Environmental Monitoring}

An abandoned mine is a complex system, with multiple variables, that can bring risks to the local community, affecting the environment and human health. It can change the landscape, producing wastes that concentrate PTEs and likely disseminate them in the surroundings, causing water and soil pollution $[3,8]$. In addition, the presence of underground works and waste piles may contribute to ground subsidence.

In the case of the São Pedro da Cova mine, there is a higher level of complexity, since the mine's waste pile has been self-burning since 2005, which can influence its physical stability, as well as the chemical composition and concentration of the contaminants present $[25,51]$, and, consequently, its migration and dissemination capability [32,51]. This complexity necessitates an integrative approach gathering different methodologies that would be able to contemplate multiple variables regarding abandoned mine monitoring. The developed Coal Mine GIS open-source application is the tool that permits monitoring of environmental parameters, allowing the creation of risks maps representing their spatial and temporal variations $[24,55]$.

The self-burning has been occurring since 2005 and nothing has ever been done to extinguish the combustion. Even though the combustion seems less intense since 2013, the long-term environmental impacts are of significant concern, principally those related to emissions of gaseous organic compounds and particulate matter to the atmosphere, and with the leaching of PTEs to the surrounding areas (affecting soils and waters). As a consequence of the combustion of the coaly waste materials, the mode of occurrence of some elements can change and concentrate due to the loss of organic matter, due to its solubilization or volatilization. The results obtained in this integrative approach allow the comprehension of the combustion process and the identification of potential evolutive scenarios in the São Pedro da Cova waste pile, since a significant part of the waste pile was not affected by the self-burning. Only with this information will it be possible to define the proper mitigation and prevention actions by decision-makers.

The integrated multi-approach of the studied environmental parameters for the São Pedro da Cova waste pile monitoring was performed considering both the evaluation of the dynamics of the self-burning, its effects on this complex structure and the consequences in the surrounding areas, namely, in soils and waters $[36,66]$. This is particularly relevant because, as mentioned before, the São Pedro da Cova waste pile is located in a populated area. For this purpose, remote sensing using a UAV, together with the traditional methodologies, proved to be a successful approach for the collection of the information for environmental assessment and monitoring.

Furthermore, the data generated within this project are being stored and manipulated in a relational database that is continuously updated with new information [52]. This process facilitates data management as the updates are easier to conduct and provide immediate comparisons with related data from previous campaigns. This integrated multi-approach provides a global understanding of the effects of abandoned mines on the surrounding environment, allowing the analysis of each monitored parameters' evolution with time, which provides a good idea of the current dynamics of the different processes involved.

In future campaigns, the GIS application will be updated, and a web map application will be developed to incorporate and integrate all the data obtained. The web application 
will be developed using the Leaflet library, Javascript and the Hypertext Preprocessor (PHP) programming language. It will be composed of: (i) the standard basic tools such as pan, zoom in/out and search bar for places and/or coordinates; (ii) the possibility to access one or more layers, including the overlapping between them; and (iii) a slide bar with the chronological dates, where the user can evaluate the variation over time. Other functionalities will be added to the web GIS application.

\section{Conclusions}

Mining activities originate environmental impacts involving a great variety of physi$\mathrm{cal}$, chemical and biological aspects. Adequate environmental monitoring of these complex systems requires multidisciplinary, interdisciplinary and, even, transdisciplinary perspectives, which may be achieved by means of an integrated multi-approach, encompassing interrelated observations in the geosphere, hydrosphere, atmosphere and biosphere.

GIS provides a suitable platform for dealing with large sets of data obtained through the application of multiple methods and techniques, which are usually hard to integrate. Efficient assessment of soil, water and atmospheric pollution by coal mining activities should rely on comprehensive and realistic conceptual models, which benefit from this research strategy approach, to support well-founded technical decisions.

In this study, different approaches were applied in order to monitor the São Pedro da Cova coal mine waste pile and the surrounding areas. From the temperature and topographic analysis performed, it was concluded that the waste pile temperature is directly influenced by the air temperature. Nevertheless, in an area with approximately $200 \mathrm{~m}^{2}$, near the base of the waste pile, self-burning is still active, reaching surface temperatures over $50{ }^{\circ} \mathrm{C}$, independently from the season and air temperature. The LULC and NDVI analysis also allowed concluding that vegetation only appears in the area with lower temperatures. It is noted that the presence of vegetation is extremely important, as it contributes to minimizing soil erosion in the waste pile, helping its stabilization process. A general tendency for a decrease in altimetric values was also checked, corroborating the hypothesis that, as self-burning occurs, the volume of material in the waste pile may be reducing. The elemental concentrations registered in PTEs from the soils that surround the São Pedro da Cova mine classify these soils as inappropriate for agriculture. The contamination rates seem to be stable or very slow for most of the area, but some exceptions must be highlighted. Samples located preferentially in urbanized areas, upstream of the mine, show a moderate increase in $\mathrm{As}, \mathrm{Pb}, \mathrm{Mo}, \mathrm{Cu}, \mathrm{Zn}, \mathrm{Co}, \mathrm{Ni}$ and $\mathrm{Ag}$, and samples included in the waste pile drainage basin suffered an increase in $\mathrm{V}, \mathrm{Be}, \mathrm{Cr}$ and Ta concentrations, supporting that there are multiple types of contamination sources contributing differently to the concentration of PTEs and other elements registered in soils. The possible hydrogeochemical influence on groundwater of the waste pile was also investigated, and the results point out that this influence is most likely inexistent. The chemical quality of groundwater and surface water affected by coal mining activities is inadequate for human activities, namely, domestic and agricultural use. All the data were integrated and analyzed in the Coal Mine GIS application, specifically developed for this purpose, which allowed the overlapping and integration of all the information.

Author Contributions: Conceptualization, A.T.; methodology, A.T., P.S., J.E.M., J.R., C.M., L.D., C.R.d.A. and D.F.; software, A.T., P.S., C.R.d.A. and L.D.; validation, P.S., J.E.M. and J.R.; formal analysis, A.T., P.S., J.E.M., J.R., C.M., L.D., C.R.d.A. and D.F.; investigation, A.T., P.S., J.E.M., J.R., C.M., A.M., L.D., C.R.d.A. and D.F.; writing-original draft preparation, A.T.; writing-review and editing, A.T., P.S., J.E.M., J.R., C.M., L.D., C.R.d.A. and D.F. All authors have read and agreed to the published version of the manuscript.

Funding: This work was funded through the Foundation for Science and Technology, through the CoalMine project with the ref. POCI-01-0145-FEDER-030138, 02-SAICT-2017 and by FEDER funding through the COMPETE 2020 programme and framed within the activities of the UIDB/04683/2020. ICT is financed through the European Regional Development Fund (COMPETE 2020), with ref. POCI-01-ERDF-007690. 
Institutional Review Board Statement: Not applicable.

Informed Consent Statement: Not applicable.

Acknowledgments: The authors want to acknowledge João Rocha, João Fernandes, Vitor Martins, José Alberto Gonçalves, Rita Fonseca and Catarina Pinho for the support given in several steps of the CoalMine project.

Conflicts of Interest: The authors declare no conflict of interest.

\section{References}

1. Li, J.; Pei, Y.; Zhao, S.; Xiao, R.; Sang, X.; Zhang, C. A Review of Remote Sensing for Environmental Monitoring in China. Remote Sens. 2020, 12, 1130. [CrossRef]

2. Peng, J.; Zong, M.; Hu, Y.; Liu, Y.; Wu, J. Assessing Landscape Ecological Risk in a Mining City: A Case Study in Liaoyuan City, China. Sustainability 2015, 7, 8312-8334. [CrossRef]

3. Malaviya, S.; Munsi, M.; Oinam, G.; Kumar Joshi, P. Landscape approach for quantifying land use land cover change (1972-2006) and habitat diversity in a mining area in Central India (Bokaro, Jharkhand). Environ. Monit. Assess. 2010, 170, 215-229. [CrossRef] [PubMed]

4. Liao, X.; Li, W.; Hou, J. Application of GIS Based Ecological Vulnerability Evaluation in Environmental Impact Assessment of Master Plan of Coal Mining Area. Procedia Environ. Sci. 2013, 18, 271-276. [CrossRef]

5. Liu, X.; Zhou, W.; Bai, Z. Vegetation coverage change and stability in large open-pit coal mine dumps in China during 1990-2015. Ecol. Eng. 2016, 95, 447-451. [CrossRef]

6. Bayliss, P.; Van Dam, R.; Bartolo, E. Quantitative Ecological Risk Assessment of the Magela Creek Floodplain in Kakadu National Park, Australia: Comparing Point Source Risks from the Ranger Uranium Mine to Diffuse Landscape-Scale Risks. Hum. Ecol. Risk Assess. Int. J. 2012, 18, 115-151. [CrossRef]

7. Solgi, E.; Esmaili-Sari, A.; Riyahi-Bakhtiari, A.; Hadipour, M. Soil Contamination of Metals in the Three Industrial Estates, Arak, Iran. Bull. Environ. Contam. Toxicol. 2012, 88, 634-638. [CrossRef]

8. Wu, Y.; Xu, Y.; Zhang, J.; Hu, S.; Liu, K. Heavy metals pollution and the identification of their sources in soil over Xiaoqinling gold-mining region, Shaanxi, China. Environ. Earth Sci. 2011, 64, 1585-1592. [CrossRef]

9. Rađenović, A.; Medunić, G.; Saikia, B.K. Comparative review of Croatian and Indian air pollution studies with emphasis on pollutants derived by coal combustion. Rud. Geol. Naft. Zb. 2017, 32, 33-43. [CrossRef]

10. Burke Johnson, R.; Onwuegbuzie, A.J.; Turner, L.A. Toward a Definition of Mixed Methods Research. J. Mix. Methods Res. 2007, 1, 112-133. [CrossRef]

11. Abou Zakhem, B.; Hafez, R. Hydrochemical, isotopic and statistical characteristics of groundwater nitrate pollution in Damascus Oasis (Syria). Environ. Earth Sci. 2015, 74, 2781-2797. [CrossRef]

12. Smith, D.N.I.; Ortega-Camacho, D.; Acosta-González, G.; Maria Leal-Bautista, R.; Fox, W.E.; Cejudo, E. A multi-approach assessment of land use effects on groundwater quality in a karstic aquifer. Heliyon 2020, 6, e03970. [CrossRef]

13. Duarte, L.; Teodoro, A.; Barbosa, D. Radio Astronomy Demonstrator: Assessment of the Appropriate Sites through a GIS Open Source Application. ISPRS Int. J. Geo-Inf. 2016, 5, 209. [CrossRef]

14. Yang, Y.; Tang, X.-I.; Li, Z.-H. Land use suitability analysis for town development planning in Nanjing hilly areas: A case study of Tangshan new town, China. J. Mt. Sci. 2021, 18, 528-540. [CrossRef]

15. Saraswat, S.; Digalwar, A.K.; Yadav, S.; Kumar, G. MCDM and GIS based modelling technique for assessment of solar and wind farm locations in India. Renew. Energy 2021, 169, 865-884. [CrossRef]

16. Kazuva, E.; Zhang, J.; Tong, Z.; Liu, X.-P.; Memon, S.; Mhache, E. GIS- and MCD-based suitability assessment for optimized location of solid waste landfills in Dar es Salaam, Tanzania. Environ. Sci. Pollut. Res. 2021, 28, 11259-11278. [CrossRef]

17. Sarkar, B.C.; Mahanta, B.N.; Saikia, K.; Paul, P.R.; Singh, G. Geo-environmental quality assessment in Jharia coalfield, India, using multivariate statistics and geographic information system. Environ. Geol. 2007, 51, 1177-1196. [CrossRef]

18. Lin, Y.; Hoover, J.; Beene, D.; Erdei, E.; Liu, Z. Environmental risk mapping of potential abandoned uranium mine contamination on the Navajo Nation, USA, using a GIS-based multi-criteria decision analysis approach. Environ. Sci. Pollut. Res. 2020, 27, 30542-30557. [CrossRef]

19. Flores, H.; Lorenz, S.; Jackisch, R.; Tusa, L.; Contreras, I.C.; Zimmermann, R.; Gloaguen, R. UAS-Based Hyperspectral Environmental Monitoring of Acid Mine Drainage Affected Waters. Minerals 2021, 11, 182. [CrossRef]

20. Ferrier, G. Application of Imaging Spectrometer Data in Identifying Environmental Pollution Caused by Mining at Rodaquilar, Spain. Remote Sens. Environ. 1999, 68, 125-137. [CrossRef]

21. Choe, E.; van der Meer, F.; van Ruitenbeek, F.; van der Werff, H.; Smeth, B.; Kim, K.-W. Mapping of heavy metal pollution in stream sediments using combined geochemistry, field spectroscopy, and hyperspectral remote sensing: A case study of the Rodalquilar mining area, SE Spain. Remote Sens. Environ. 2008, 112, 3222-3233. [CrossRef]

22. Booysen, R.; Jackisch, R.; Lorenz, S.; Zimmermann, R.; Kirsch, M.; Nex, P.A.M.; Gloaguen, R. Detection of REEs with lightweight UAV-based hyperspectral imaging. Sci. Rep. 2020, 10, 17450. [CrossRef] 
23. Kopeć, A.; Trybała, P.; Głąbicki, D.; Buczyńska, A.; Owczarz, K.; Bugajska, N.; Kozińska, P.; Chojwa, M.; Gattner, A. Application of Remote Sensing, GIS and Machine Learning with Geographically Weighted Regression in Assessing the Impact of Hard Coal Mining on the Natural Environment. Sustainability 2020, 12, 9338. [CrossRef]

24. Duarte, L.; Teodoro, A.C.; Gonçalves, J.A.; Ribeiro, J.; Flores, D.; Lopez-Gil, A.; Dominguez-Lopez, A.; Angulo-Vinuesa, X.; Martin-Lopez, S.; Gonzalez-Herraez, M. Distributed Temperature Measurement in a Self-Burning Coal Waste Pile through a GIS Open Source Desktop Application. ISPRS Int. J. Geo-Inf. 2017, 6, 87. [CrossRef]

25. Ribeiro, J.; Ferreira da Silva, E.; Flores, D. Burning of coal waste piles from Douro Coalfield (Portugal): Petrological, geochemical and mineralogical characterization. Int. J. Coal Geol. 2010, 81, 359-372. [CrossRef]

26. Ribeiro, J.; Flores, D.; Ward, C.R.; Silva, F.O. Identification of nanominerals and nanoparticles in burning coal waste piles from Portugal. Sci. Total Environ. 2010, 408, 6032-6041. [CrossRef]

27. Ribeiro, J.; Silva, T.; Graciano Mendonca Filho, F.; Flores, D. Polycyclic aromatic hydrocarbons (PAHs) in burning and non-burning coal waste piles. J. Hazard. Mater. 2012, 199-200, 105-110. [CrossRef]

28. Ribeiro, J.; Taffarel, S.R.; Sampaio, C.H.; Flores, D.; Silva, L.F. Mineral speciation and fate of some hazardous contaminants in coal waste pile from anthracite mining in Portugal. Int. J. Coal Geol. 2013, 109-110, 15-23. [CrossRef]

29. Ribeiro, J.; Sant'Ovaia, H.; Gomes, C.; Ward, C.; Flores, D. Mineralogy and Magnetic Parameters of Materials Resulting from the Mining and Consumption of Coal from the Douro Coalfield, Northwest Portugal in Coal and Peat Fires: A Global Perspective. In Coal and Peat Fires: A Global Perspective; Elsevier: Amsterdam, The Netherlands, 2015; Volume 3, pp. 493-508.

30. Ribeiro, J.; Viveiros, D.; Ferreira, J.; Suárez-Ruiz, I.; Santos, J.L.; Baptista, J.M.; Flores, D. Volatile organic compounds emitted from self-burning coal waste piles in Spain and Portugal: Environment and human health concerns. In Progress in Medical Geology; Ibaraki, M., Mori, H., Eds.; Cambridge Scholars Publishing: Newcastle Upon Tyne, UK, 2017; pp. $229-247$.

31. Ribeiro, J.; Viveiros, D.; Ferreira, J.; Lopez-Gil, A.; Dominguez-Lopez, A.; Martins, H.; Perez-Herrera, R.; Lopez-Aldaba, A.; Duarte, L.; Pinto, A.; et al. ECOAL Project-Delivering Solutions for Integrated Monitoring of Coal-Related Fires Supported on Optical Fiber Sensing Technology. Appl. Sci. 2017, 7, 956. [CrossRef]

32. Ribeiro, J.; Flores, D. Occurrence, leaching, and mobility of major and trace elements in a coal mining waste dump: The case of Douro Coalfield, Portugal. Energy Geosci. 2021, 2, 121-128. [CrossRef]

33. Kottek, M.; Grieser, J.; Beck, C.; Rudolf, B.; Rubel, F. World Map of the Köppen-Geiger climate classification updated. Meteorol. Zeitschrift 2006, 15, 259-263. [CrossRef]

34. Pinto de Jesus, A. Evolução sedimentar e tectónica da Bacia Carbonífera do Douro (Estefaniano C inferior, NW de Portugal). Cad. Lab. Xeolóxico Laxe 2003, 28, 107-125.

35. Medeiros, A.; Pereira, E.; Moreira, A. Notícia Explicativa da Folha 9-D Penafiel da Carta Geológica de Portugal à Escala 1:50000; Serviços Geológicos de Portugal: Lisboa, Portugal, 1980.

36. Rocha, J.; Santos, P.; Ribeiro, J.; Espinha Marques, J.; Mansilha, C.; Flores, D. Hydrogeochemical characterization of effluents from São Pedro da Cova coal mine (Gondomar). Comun. Geológicas 2020, 107, 129-132.

37. Isabel Soto-Estrada, M.; Correa-Echeveri, E.; Correa Echeverri, S. Thermal analysis of urban environments in Medellin, Colombia, using an unmanned aerial vehicle (UAV). J. Urban Environ. Eng. 2017, 11, 142-149. [CrossRef]

38. Agisoft. Agisoft Metashape. Available online: https://www.agisoft.com/ (accessed on 1 December 2020).

39. Esri. ArcMap. Available online: https://www.esri.com/en-us/arcgis/products/arcgis-desktop/resources (accessed on 1 December 2020).

40. Rossini, M.; Di Mauro, B.; Garzonio, R.; Baccolo, G.; Cavallini, G.; Mattavelli, M.; De Amicisa, M.; Colombo, R. Rapid melting dynamics of an alpine glacier with repeated UAV photogrammetry. Geomorphology 2018, 304, 159-172. [CrossRef]

41. Enderle, D.M.; Weih, R.C., Jr. Integrating Supervised and Unsupervised Classification Methods to Develop a More Accurate Land Cover Classification. J. Ark. Acad. Sci. 2005, 59, 65-73.

42. Campbell, J.B. Introduction to Remote Sensing, 3rd ed.; The Guilford Press: New York, NY, USA, 2002.

43. Teodoro, A.; Pais-Barbosa, J.; Gonçalves, H.; Veloso-Gomes, F.; Taveira-Pinto, F. Identification of beach hydromorphological patterns/forms through image classification techniques applied to remotely sensed data. Int. J. Remote Sens. 2011, 32, 7399-7422. [CrossRef]

44. Rouse, J.; Haas, R.H.; Schell, J.A.; Deering, D. Monitoring vegetation systems in the great plains with ERTS. In Proceedings of the 3rd ERTS Symposium, Washington, DC, USA, 10-14 December 1973; pp. 309-317.

45. Duarte, L.; Teodoro, A.C.; Gonçalves, H. Deriving phenological metrics from NDVI through an open source tool developed in QGIS. Earth Resour. Environ. 2014, 132, 924511. [CrossRef]

46. Hmimina, G.; Dufrêne, E.; Pontailler, J.-Y.; Delpierre, N.; Aubinet, M.; Caquet, B.; De Grandcourt, A.; Burban, B.; Flechard, C.R.; Granier, A.; et al. Evaluation of the potential of MODIS satellite data to predict vegetation phenology in different biomes: An investigation using ground-based NDVI measurements. Remote Sens. Environ. 2013, 132, 145-158. [CrossRef]

47. Mansilha, C.; Melo, A.; Flores, D.; Espinha Marques, J.; Ribeiro, J. Abandoned coal mines and groundwater pollution: A case study in S. Pedro da Cova, N Portugal. In Proceedings of the 46th IAH Congress, Málaga, Spain, 22-27 September 2019.

48. Baird, R.; Bridgewater, L. Standard Methods for the Examination of Water and Wastewater (SMWW), 23rd ed.; American Public Health Association: Washington, DC, USA, 2017.

49. Rodier, B.J. Legube, l'Analyse de l'Eau-Eaux Naturelles, Eaux Residuaires, Eau de Mer, 10th ed.; DUNOD: Malakoff, France, 2016.

50. Kumar Jain, M.; Das, A. Impact of Mine Waste Leachates on Aquatic Environment: A Review. Curr. Pollut. Rep. 2017, 3, 31-37. [CrossRef] 
51. Gombert, P.; Sracek, O.; Koukouzas, N.; Gzyl, G.; Tuñon Valladares, S.; Frączek, R.; Klinger, C.; Bauerek, A.; Enrique Álvarez Areces, J.; Chamberlain, S.; et al. An Overview of Priority Pollutants in Selected Coal Mine Discharges in Europe. Mine Water Environ. 2019, 38, 16-23. [CrossRef]

52. Espinha Marques, J.; Martins, V.; Santos, P.; Ribeiro, J.; Mansilha, C.; Melo, A.; Rocha, F.; Flores, D. Changes Induced by Self-Burning in Technosols from a Coal Mine Waste Pile: A Hydropedological Approach. Geosciences 2021, 11, 195. [CrossRef]

53. Lv, J.; Wang, Y. Multi-scale analysis of heavy metals sources in soils of Jiangsu Coast, Eastern China. Chemosphere 2018, 212, 964-973. [CrossRef]

54. Fan, M.; Margenot, A.J.; Zhang, H.; Lal, R.; Wu, J.; Wu, P.; Chen, F.; Gao, C. Distribution and source identification of potentially toxic elements in agricultural soils through high-resolution sampling. J. Environ. Pollut. 2020, 263 Pt B, 114527. [CrossRef]

55. Duarte, L.; Teodoro, A.; Fernandes, J.; Santos, P.; Flores, D. An Integrated Environmental Monitoring Approach through the Development of Coal Mine, a GIS Open Source Application. In Proceedings of the 6th International Conference on Geographical Information Systems Theory, Applications and Management, Prague, Czech Republic, 7-9 May 2020; pp. 286-293. [CrossRef]

56. Satllman. Available online: https: / / stallman.org. (accessed on 20 May 2020).

57. Instituto Português do Mar e da Atmosfera (IPMA). 2021. Available online: https://www.ipma.pt/en/ (accessed on 14 December 2020).

58. Teodoro, A.C.; Fernandes, J.; Santos, P.; Duarte, L.; Gonçalves, J.A.; Flores, D. Monitoring of soil movement in a self-burning coal waste pile with UAV imagery. Proc. SPIE 2020, 11534. [CrossRef]

59. SNAP. Available online: https://step.esa.int/main/download/snap-download/ (accessed on 15 February 2020).

60. MacQueen, J. Some methods for classification and analysis of multivariate observations. In Proceedings of the Fifth Berkeley Symposium on Mathematical Statistics and Probability; University of California Press: Berkeley, CA, USA, 1967; pp. $281-297$.

61. Jensen, J.R. Remote Sensing of the Environment: An Earth Resource Perspective; Prentice Hall: Upper Saddle River, NJ, USA, 2000.

62. Ayers, R.S.; Westcot, D.W. Water Quality for Agriculture; FAO Irrigation and Drainage Paper; FAO: Rome, Italy, 1994.

63. Directive (EU) 2020/2184 of the European Parliament and of the Council of 16 December 2020 on the quality of water intended for human consumption. Off. J. Eur. Union 2020. Available online: https:/ / eur-lex.europa.eu/eli/dir/2020/2184/oj (accessed on 25 November 2020).

64. Gray, N.F. Field assessment of acid mine drainage contamination in surface and ground water. Environ. Geol. 1996, 27, 358-361. [CrossRef]

65. Morin, K.A.; Hutt, N.M. Environmental Geochemistry of Minesite Drainage: Practical Theory and Case Studies; MDAG Publishing: Vancouver, BC, Canada, 2001; pp. 61-82.

66. Santos, P.; Espinha Marques, J.; Ribeiro, J.; Flores, D. Caracterização da contaminação dos solos da envolvente da escombreira da antiga mina de carvão de São Pedro da Cova. Comun. Geológicas 2020, 107, 151-154.

67. APA. Solos Contaminados—Guia Técnico, Valores de Referência para o Solo; APA: Lisboa, Portugal, 2019; p. 73.

68. Guo, G.; Wu, F.; Xie, F.; Zhang, R. Spatial distribution and pollution assessment of heavy metals in urban soils from southwest China. J. Environ. Sci. 2012, 24, 410-418. [CrossRef]

69. Yuan, X.; Xue, N.; Han, Z. A meta-analysis of heavy metals pollution in farmland and urban soils in China over the past 20 years. J. Environ. Sci. 2021, 101, 217-226. [CrossRef]

70. Ribeiro, J.; Ferreira da Silva, E.; Pinto de Jesus, A.; Flores, D. Petrographic and geochemical characterization of coal waste piles from Douro Coalfield (NW Portuga). Int. J. Coal Geol. 2011, 87, 226-236. [CrossRef]

71. Finkelman, R.B.; Palmer, C.A.; Wang, P. Quantification of the modes of occurrence of 42 elements in coal. Int. J. Coal Geol. 2018, 185, 138-160. [CrossRef]

72. Vallejuelo, S.; Gredilla, A.; Da Boit, K.; Teixeira, E.C.; Sampaio, C.H.; Madariaga, J.M.; Silva, L. Nanominerals and potentially hazardous elements from coal cleaning rejects of abandoned mines: Environmental impact and risk assessment. Chemosphere 2017, 169, 725-733. [CrossRef]

73. PostGIS. Spatial and Geographic Objects for PostgreSQL. Available online: http:/ / postgis.net/ (accessed on 31 July 2020). 